\title{
Modernising the Law on Escape, Prison Breach \& Rescue
}

\author{
Graham S McBain ${ }^{1,2}$ \\ ${ }^{1}$ Peterhouse, Cambridge, UK \\ ${ }^{2}$ Harvard Law School, USA \\ Correspondence: Graham S McBain, 21 Millmead Terrace, Guildford, Surrey, GU2 4AT, UK. E-mail: \\ gsmcbain@aol.com
}

Received: April 22, 2014 Accepted: July 17, 2014 Online Published: November 15, 2014

doi:10.5539/res.v6n4p147 URL: http://dx.doi.org/10.5539/res.v6n4p147

\begin{abstract}
The present English law on escape, prison breach and rescue is unnecessarily complicated and subject to the remants of history, when the death penalty (as well as drawing, hanging and quartering in the case of treason) could still beimposed. This area of the law should be modernised, in order to reflect the twenty-first century.
\end{abstract}

Keywords: escape, prison breach,rescue, modernisation of the law, creating new offences of escape and assistingescape, dovetailing them with statutory provisions, abolishing criminalliability for negligent escape, abolishing criminal liability for voluntarily assisting escape in the case of a private person, abolishing fines

\section{Introduction}

There are a number of areas of English criminal law which require modernisation. The law in relation to escape, prison breach and rescue is one. At present, it is an amalgam of common law and legislation. This - and its rather tortuous legal history-has resulted in confusion and unnecessary complexity. The purpose of this article is to review this area of law and to propose modern legislative provisions which are simpler, as well as reflect the need for consistency in terms of punishment. In respect of the development of this area of law:

- In early medieval times - with the exception of the main London prisons - prisons were often no more than cellars or rooms set aside in a building. In practice, therefore, they were often not difficult to escape from;

- Until 1967, ${ }^{1}$ crimes were categorised into treasons, felonies and misdemeanours. ${ }^{2}$ The first two merited the death penalty. The first also comprised an excruciating form of punishment. ${ }^{3}$ Given this, it was not unexpected that prisoners charged with treason or felony - or, even more so, convicted of the samewould seek to escape or request others to rescue them;

- Until the $18^{\text {th }}$ century, the salaries of jailers (gaolers) usually arose by way of charges imposed on prisoners (for food, bedding etc.). Further, their status was lowly and many had no professional skills. Thus, it was not unexpected that they might—-for money-help prisoners escape, or through negligence, permit the same.

Against the above background, legal concepts of escape, prison breach and rescue developed. The distinction between the first two hinged on whether force was used by the escapee. ${ }^{4}$ If force was used, it was prison breach,

\footnotetext{
${ }^{1}$ Criminal Law Act 1967, s 1(1) 'All distinctions between felony and misdemeanour are hereby abolished. (2) Subject to the provisions of this Act, on all matters on which a distinction has previously been made between felony and misdemeanour, including mode of trial, the law and practice in relation to all offences cognisable under the law of England and Wales (including piracy) shall be the law and practice applicable at the commencement of this Act in relation to misdemeanour.' It may be noted these three categorisations were not exclusive. Minor crimes tended to be called 'offences' and this term remains in use today. Misdemeanours in former times were also called 'trespasses.' See also Criminal Law Revision Committee, $7^{\text {th }}$ Report. Cmnd 2659.

${ }^{2}$ Treason is a felony, albeit of a higher class. HW Disney \& H Gundry, The Criminal Law (London, Stevens \& Sons, 1895), p 2 'Treasons are sometimes classed by themselves as crimes of even a higher order than felonies, but all treasons are felonies, though, of course, all felonies are not treasons.'

${ }^{3}$ Drawing, hanging and quartering, see GS McBain, Abolishing the Crime of Treason (2007) 81 Australian Law Journal, pp 94-134, n 32.

${ }^{4}$ When there was 'no act of force' Hale termed it a 'simple escape' (others just referred to escape, as did the courts). When an act of force was used it was termed prison breach. See M Hale, The History of the Pleas of the Crown. London, E \& R Nutt \& R Gosling, 1736 (rep Law Book Exchange, 2004), vol 1, p 590. W Hawkins, A Treatise on Pleas of the Crown, E \& R Nutt \& R Gosling, Savoy (3rd ed, 1739), book 2, p 125 noted that prison breach involved, 'some real force or violence'. JW Cecil Turner, Russell on Crime (12 ${ }^{\text {th }}$ ed, 1964), p 330 'Where a person who is lawfully in prison effects his escape by force or against the gaoler's will, the offence is usually called prison breaking.' See
} 
not escape, and this had important consequences. If prison breach, the crime was a felony (meriting the death penalty). If escape, it was a misdemeanour. ${ }^{5}$

- Rescue involved a third party using force to free another. ${ }^{6}$ Thus, the law on prison breach and rescue was similar in many points of law-including punishment; ${ }^{7}$

- In respect of the jailer (or constable) responsible for the prisoner, a distinction was drawn between whether he helped the prisoner escape (voluntary escape) or was simply negligent (negligent escape). ${ }^{8}$ The first being more culpable, he merited a greater punishment. ${ }^{9}$

In respect of these crimes, in an attempt to ensure the gallows were not thwarted, until 1295, the law was especially harsh. A person on-or convicted of - a capital charge (i.e. treason or felony) who escaped or committed prison breach ${ }^{10}$ was punishable with death - even if subsequently found innocent of the charge. A jailer who permitted the same also merited death. So did any rescuer. After 1295, this was ameliorated somewhat by legislation. Over the ensuing centuries, the law in respect of these crimes became more and more convoluted - not least because of the changing nature of prisons and various exceptions. Also, legislation continued to intrude into this area of common law. In modern times, matters in relation to prisons-and escapeare very different to the past, viz:

- Prisons (as well as police cells) are much more secure than hitherto and prison officers (as well as police officers) are professionals paid by the State to maintain their captives, captive;

- With the temporary release of prisoners on licence as they near the end of their sentence, such escapes as there are, tend to arise from a failure to return to prison at the end of leave or they comprise escapes outside the prison gates;

- The distinction between treasons, felonies and misdemeanours has been abolished. The death penalty has also been abolished for all offences. As a result, the distinction between escape (where no force was used) and prison breach (where force was used) is not of relevance vis-a-vis the crime (it used to matter, when this related to whether the crime merited death or not).

Given this, much of the rationale behind the concepts of escape, prison breach and rescue has now gone. As a result, it is asserted these offences should be amalgamated, to an extent. Also, today, it is asserted that only legislation should govern this area, common law provisions being abolished. When considering this area of law, there are a few legal texts, as well as some useful general works. ${ }^{11}$ The most useful of the former are:

- W Staunford, Pleas of the Crown (1557); ${ }^{12}$

- $\quad$ E Coke, Institutes of the Laws of England (1628-41); ${ }^{13}$

- $\quad$ W Hawkins, A Treatise of the Pleas of the Crown (1716-1824); ${ }^{14}$

- $\quad$ M Hale, The History of the Pleas of the Crown (published 1736, written 1640's); ${ }^{15}$

also $A G v$ Hobart (1630) Cro Car 210 (79 ER 784) 'And Calthrop [counsel] made this difference betwixt breach of prison and escape: the first, is against the gaoler's will, the other is with his consent, but in both the prisoner is punishable: where unto the whole court agreed.' The statement of Russell and in $A G v$ Hobart are not wholly clear in that prison breach can also occur where the jailer is negligent.

${ }^{5}$ Therefore, if a prisoner walked out of an open prison door or escaped without using 'any kind of force or violence' it was an escape (a misdemeanour) and not prison breach (a felony). This was the position post-1295 (see 5). See Hawkins, n 4, book 2, p 125.

${ }^{6}$ Hale, $\mathrm{n} 4$, vol 1, p 590 'When the escape is caused by a stranger...this is ordinarily called a rescue.' See also $\mathrm{n} 7$.

${ }^{7}$ Hawkins, n 4, book 2, p 139 'The offence of a stranger in forcibly freeing another from an arrest, comes under the notion of rescous, which in most instances is of the same nature with the offence of breaking prison...'

${ }^{8}$ Hale, n 4, vol 1, p 590 'A voluntary escape is when any person having a felon [or anyone else] lawfully in his custody voluntary permits him to escape from it or go at large.'

${ }^{9}$ Given the ramshackle state of prisons (and constable lock-ups) in earlier times, it was probably difficult to determine if a prisoner escaped through the connivance of the jailer (or constable) or his incompetence. This helps explain why few jailers (or constables) experienced the full rigour of the law in the case where felons escaped. Instead, they tended to be fined or lose their office.

${ }^{10}$ That is, whether the prisoner used force or not.

${ }^{11}$ For works on early English prisons, see RB Pugh, Imprisonment in Medieval England (Cambridge UP, 1968); N Morris \& DJ Rothman, The Oxford History of the Prison (NY, 1998); J Bellamy, Crime and Public Order in England in the later Middle Ages (London, Routledge \& Kegan Paul, 1973); C Harding et al, Imprisonment in England and Wales, A Concise History (London, Croom Helm, 1985) and EF Du Cane, The Punishment and Prevention of Crime (Macmillan \& Co, 1885) (chs $3 \& 4$ are a useful summary of jails in early and later times). See also E Powell, Criminal Justice in the Reign of Henry V (Oxford, Clarendon, 1989) and G Ives, A History of Penal Methods (1914, reprint 1970 Patterson Smith), chs 1 (penal methods in the Middle Ages) \& 5 (origin of cell prisons).

${ }^{12}$ W Staunford, Les Plees del Coron (Richard Tottell,1557). See also F Pulton, De Pace Regis et Regni (1st ed 1609, rep Professional Books Ltd), pp 147-52. Also, A Fitzherbert \& R Crompton, L'Office et Auchtoritie de Justices de Peace (1584, rep Professional Books Ltd, 1972).

${ }^{13} \mathrm{E}$ Coke, Institutes of the Laws of England. (W Clarke \& Sons, London, last ed, 1824). Also useful is M Dalton, The Countrey Justice (London, printed for the Society of Stationers, 1619).

${ }^{14}$ See $n$ 4. The first edition of Hawkins was in $1716-21$. The last edition (the $8^{\text {th }}$ ed) was in 1824. 
- W Blackstone, Commentaries on the Laws of England (1765-9); $;^{16}$

- $\quad$ W Archbold, Criminal Pleading, Evidence and Practice (1822-2014); ${ }^{17}$

- Halsbury, Laws of England. ${ }^{18}$

Apart from Archbold, Halsbury and Blackstone's Criminal Procedure, ${ }^{19}$ modern criminal texts contain nothing (or next to nothing) on these crimes. ${ }^{20}$ It may also be noted that Archbold mainly refers to Coke (published 162841), Hawkins (last ed, 1824) and Russell (last ed, 1964). However, since many changes have occurred since these writers wrote, it is often inadvisable to cite them without further explanation (not least because a number of their statements were conditional). ${ }^{21}$

\section{Prisons in Early Times}

Prisons - the word derives from the medieval latin word prisio, meaning to arrest ${ }^{22}$-are ancient in being. In terms of England, it is likely that the Anglo-Saxons had prisons and this can be traced to the time of king Alfred (871-99). However, little is known about the nature — and extent—of these prisons. Nor for what crimes they were used. ${ }^{23}$ As to the use of prisons after the Norman Conquest in 1066, the following may be noted:

- William I (1066-87) built the first royal prison, the Tower of London. It was likely used as such from $1100 .{ }^{24}$ Other early royal prisons comprised the Fleet prison in London $(1197-1814){ }^{25}$ and the 'baulk house' at Winchester (established between 1103-15). ${ }^{26}$ Powerful magnates (including ecclesiastics) also had their 'private' prisons. ${ }^{27}$ Early on, it seems that sheriffs became involved in maintaining prisons; ${ }^{28}$

${ }^{15} \mathrm{M}$ Hale, The History of the Pleas of the Crown (printed for E \& R Nutt \& R Gosling, 1736).

${ }^{16} \mathrm{~W}$ Blackstone, Commentaries on the Laws of England. (Oxford, Clarendon Press, $1^{\mathrm{st}} \mathrm{ed}, 1765-9$, University of Chicago Press rep 1979).

${ }^{17} \mathrm{JF}$ Archbold, A Summary of the law relative to Pleading and Evidence in Criminal Cases (London, 1822) and W Archbold, Criminal Pleading, Evidence and Practice (Sweet \& Maxwell, London, 2013).

${ }^{18}$ Halsbury, Laws of England (4th ed, with updates).

${ }^{19}$ Blackstone's Criminal Practice 2013 (eds A Hooper \& D Ormerod) ('Blackstone CP'). See also Archbold, Magistrates Courts Criminal Procedure ('Archbold Procedure').

${ }^{20}$ See, for example: (a) C McAlhone \& R Huxley-Binns, Criminal Law.The Fundamentals (3rd ed, 2013); (b) MJ Allen, Textbook on Criminal Law (12 $2^{\text {th }}$ ed, 2013); (c) A Ashworth \& J Horder, Principles of Criminal Law ( th $^{\text {th }}$ ed, 2013); (d) R Card et al, Criminal Law (20 ${ }^{\text {th }}$ ed, 2012); (e) CMV Clarkson \& HM Keating, Criminal Law, Text and Materials $\left(7^{\text {th }}\right.$ ed, 2010); (f) C Elliott \& F Quinn, Criminal Law ( $8^{\text {th }}$ ed, 2010); (g) R Heaton, Criminal Law (2 $2^{\text {nd }}$ ed, 2006); (h) J Herring, Criminal Law ( $8^{\text {th }}$ ed 2013); (i) M Jefferson, Criminal Law (9 $9^{\text {th }}$ ed, 2009); (j) Lacey, Wells \& Quick, Reconstructing Criminal Law. Text and Materials ( ${ }^{\text {th }}$ ed, 2010); (k) J Loveless, Complete Criminal Law. Text. Cases and Materials (3 $3^{\text {rd }}$ ed, 2012); (1) N Padfield, Criminal Law ( $7^{\text {th }}$ ed, 2010); (m) A Reed \& B Fitzpatrick, Criminal Law (4 $4^{\text {th }}$ ed, 2009); (n) AP Simester, Simester \& Sullivan's Criminal Law: Theory and Doctrine ( $5^{\text {th }}$ ed, 2013); (o) D Ormerod, Smith \& Hogan's Criminal Law (13 ${ }^{\text {th }}$ ed, 2011); (p) DJ Baker, Glanville Williams Textbook of Criminal Law ( ${ }^{\text {rd }}$ ed, 2012); (q) MJ Allen \& S Cooper, Elliott \& Woods' Cases and Materials on Criminal Law (11 ${ }^{\text {th }}$ ed, 2013); (r) M Molan, Cases and Materials on Criminal Law (4 ${ }^{\text {th }}$ ed, 2008); (s) J Martin \& T Storey, Unlocking Criminal Law ( ${ }^{\text {rd }}$ ed, 2010); (t) P Hungerford-Welch \& A Taylor, Sourcebook on Criminal Law (1997); (u) M Molan et al, Bloy \& Parry's Principles of Criminal Law ( $4^{\text {th }}$ ed, 2000); (v) W Wilson, Criminal Law $\left(4^{\text {th }}\right.$ ed, 2011). For older $20^{\text {th }}$ century texts, see JW Cecil Turner, Kenny's Outlines of Criminal Law $\left(19^{\text {th }} \mathrm{ed}, 1966\right)$ and R Cross \& PA Jones, An Introduction to Criminal Law (2 ${ }^{\text {nd }}$ ed, 1949).

${ }^{21}$ Russell (n 4) invariably cites Hawkins (n 4) or Hale (n 4).

${ }^{22}$ Oxford English Dictionary ('OED') (prison) 'the action of taking, imprisonment, captivity, a prison' and the old French preson (from the latin prendere, to seize).There was also the word carcer and the medieval latin geola, from which the word, jail, is derived. Lewis \& Short, Latin Dictionary (Oxford, Clarendon Press) ' carcer' 'an enclosed place. Hence a prison, jail (syn. custodia, vincula).'

${ }^{23}$ See Pugh, n 11, ch 1, p 1 'Imprisonment in England has no connected history before the end of the twelfth century. Its origins, however, are antique and stretch back before the days of Alfred [ie. Alfred the Great, king of Wessex, 871-99]. Once private jurisdictions begin to emerge, and this was perhaps in the eighth century, some kind of 'prison' may be presumed to exist.' Also, 'In Alfred's time the word 'prison' (carcerr) first makes its appearance in a code of laws (c. 890).' See also FL Attenborough, The Laws of the Earliest English Kings (NY, 1963).

${ }^{24}$ See generally, J Bayley, The History and Antiquities of the Tower of London (London, 1830). Also, Pugh, n 11, ch 6. Rannulf Flambard (1060-1128) administrator and bishop of Durham is said to have been its first prisoner (he was imprisoned, in effect, for extortion, being the principal tax collector for the sovereign). On 15 August 1100, he 'was arrested and imprisoned in the Tower of London-the first State prisoner to be housed there.' He is also likely the first escapee. In February 1101, he made the gaolers drunk and escaped from the Tower, using a rope. He fled to Normandy. See Oxford Dictionary of National Biography ('ODNB') which also records that 'William de Mandeville, keeper was fined heavily for his fecklessness - or complicity.' De Mandeville was fined more than $£ 2,200$ and was forced to relinquish his three most valuable demesne manors, until the debt was paid (see extract on Geoffrey de Mandeville, 1st Earl of Essex (died 1144) in ODNB. ${ }^{25}$ See generally, W Brown, The Fleet, A brief Account of the Ancient Prison called the Fleet in the City of London (London, 1843) and J Ashton, The Fleet, its River, Prison and Marriages (T Fisher Unwin, 1888). See also Harding, n 11, ch 1.

${ }^{26}$ Later prisons erected in London comprised: (a) Newgate (established 1188, closed in 1902, it was used mainly for debtors and State prisoners), see Pugh, n 11, pp 103-4; (b) Ludgate (established c 1215, closed in 1765, it was used mainly for freeman of the City of London confined for debt, trespass, contempt and other more minor offences); (c) Marshalsea (established 14th century, closed in 1842, it mainly housed debtors, those who had committed sedition and those court martialled at sea); (d) the Counters (two prisons for the sheriffs of London and Middlesex county); and (e) the Tun (a prison mainly for moral delinquents). See generally, Pugh, n 11, chs 5 \& 6 . Also Bellamy, n 11, ch 6.

${ }^{27}$ Pugh, n 11, p 3 'there is no doubt that the Normans found a number of prisons in the England that they invaded, particularly upon royal manors in the south and, in effect, they added to their number. They did this by building many castles in which both king and barons shut up their powerful adversaries and during the Anarchy [1135-53] very many of the common people also.' 
- In the Assizes of Clarendon in 1166, Henry II (1154-89) ordered sheriffs to have prisons built in each county where they did not previously exist in order to hold those accused of felonies until they could be tried by justices in eyre. ${ }^{29}$ Many towns were also ordered by the sovereign to maintain prisons;

- Some prisons were subject to a franchise from the Crown. ${ }^{30}$ That is, the sovereign sold the right to arrest, and hold, a free man. The income of the franchisee derived from the difference between the cost of maintaining the prison and the money reserved for the upkeep of the prisoner. As a result, prisoners often bore much of the cost of their upkeep. ${ }^{31}$

Over time - with the exception of the palatinates - a doctrine prevailed that all prisons were those of the sovereign, this being an aspect of his administration of justice. ${ }^{32}$ Pugh asserted the phrase prisona regis was being applied by the Chancery in the earlier years of Henry III (1216-72). ${ }^{33} \mathrm{He}$ also thought that a legal doctrine emerged that a prison-to be lawful-required express sanction from the Crown. ${ }^{34}$ As it was, in medieval times - save for the main London prisons - most prisons were small, and not very secure, affairs. Indeed, until the $18^{\text {th }}$ century-and major prison reforms commencing from the 1790 's-local prisons were a pale shadow of our modern prisons which are difficult to escape (or rescue) persons from. McGowen states, as to prisons in the $18^{\text {th }}$ century:

There were an extraordinary number of places of confinement, probably more than three hundred. The possession of such an establishment was a jealously guarded privilege for a borough, manorial, or ecclesiastical franchise holder. Yet many of these local jails consisted of no more than a gatehouse, room, or cellar. They seldom contained inhabitants for any length of time. Only a few establishments held a significant number of prisoners. The prison population of the county jail at Warwick, for instance, fluctuated considerably depending on whether it was near time for assizes....John Howard, the prisoner reformer, ${ }^{35}$ found 33 felons in the jail [at Warwick] in January 1776, along with 24 debtors, whereas in October he discovered only 7 felons and 22 debtors. London contained the largest prisons and a disproportionate share of the prison population. The most important London prison, Newgate, often held as many as 300 felons in the late eighteenth century. The city also possessed large separate establishments for debtors such as the Fleet and the Marshalsea. ${ }^{36}$

Since prisons were not well built, it was not too difficult to escape — or rescue a person — from them. That said:

- Debtors - who made up at least half the prison population in the $18^{\text {th }}$ century $^{37}$ - tended not to escape, for lack of incentive, ${ }^{38}$

\footnotetext{
${ }^{28}$ Ibid, p 4, notes that, in 1155-6, the sheriffs of London and Middlesex claimed allowances for repairing the Fleet and that, in 1157-8, the sheriff of Hampshire paid the wages of the king's jailer at Winchester.

${ }^{29}$ Ibid. See also ch 4 (county gaols). Ibid, p 59 'The sheriffs had been told in 1166 that they must cite their gaols in one of the king's boroughs or castles.' A translation of the relevant wording in the Assize of Clarendon is: 'And in the several counties where there are no jails, let them be made in a borough or in some castle of the king...to the end that the sheriffs may keep in them those who have been arrested by the officers whose function it is to do this and by their servants.' See also Bellamy, n 11, p 167. Also, F Pollock \& FW Maitland, The History of English Law (Cambridge UP, $2^{\text {nd }}$ ed, 1984 rep), pp 516-7 re the development of prisons and how the threat of imprisonment was utilised as a means of securing a fine. At p 517 'Now, so far as we can see, the justices of Henry III's reign [1216-72] used their power of imprisonment chiefly as a means of inflicting pecuniary penalties. The wrong doer but rarely goes to prison even for a moment.' See also Harding, n 11, ch 1 .

${ }^{30}$ See generally, Pugh, n 11, ch 5. Ibid, p 87 'By the late thirteenth century, if not before, the word 'prison' (prisona) had acquired a very extensive meaning. It could be applied to a county gaol maintained by a sheriff...to one of the few 'national' prisons, or to a franchise gaol owned by the lord of a liberty. The third of these classes is naturally a very broad one, for it comprises prisons owned by leading ecclesiastics and lay barons and also those in borough ownership.' See also Harding, n 11, ch 1.

${ }^{31}$ See generally, Morris, $\mathrm{n} 11$, ch 1 and Pugh, $\mathrm{n} 11$, chs $7 \& 8$.

${ }^{32}$ Pugh, n 11, p 87 'According to the doctrine that eventually prevailed, all prisons, or at any rate all prisons outside the palatinates, were the king's. They were his because they were ancillary to his justice.' Coke, n 13, vol 2, p 589 'Albeit divers lords of liberties have custody of the prisons, and some in fee, yet the prison itself is the king's pro bono publico...for no subject can have the prison itself, but the king only....' (spelling modernised).

${ }^{33}$ Ibid, p 87. Ibid, p 93 'Increasingly from Henry III's middle years justices were appointed to deliver franchise prisons in common with the gaols of counties and the prisons of urban communities. This policy prevented the franchise-holder from setting up a private criminal jurisdiction and thus making his prison a base from which to terrorise his neighbours.' Ibid, p 95 'After the end of the thirteenth century...Justices began to travel on well-defined circuits and in their peregrinations delivered not only county and municipal gaols but also the prisons of the lords of liberties.'

${ }^{34}$ Ibid, p 95.

${ }^{35}$ ODNB, n 24, John Howard (1726-90). He published his The State of the Prisons in England and Wales in 1777.

${ }^{36}$ Morris, $\mathrm{n} 11$, chapter by R McGowen, The Well-Ordered Prison: England 1780-1865, p 73. See also, JM Beattie, Crime and the Courts in England 1660-1800 (Princeton UP), 1986, pp 288-98 (especially pp 296-7 re escape).

${ }_{37}^{37}$ McGowen, n 36, p 73 'Of the 4,084 prisoners Howard [the prisoner reformer] counted on his tours [in the 1770's], 2,437 were debtors.'

${ }^{38}$ Debtors were often housed outside the prison in a 'liberty' or were allowed to leave the prison with a minder. Further, legislation in 1670 sought to separate criminals from debtors. McGowen, n 36, p 75. It may also be noted that, from the 18th century onwards, jailers became
} 
- Those who did, however, were felons and, more rarely, traitors - in order to avoid the death penalty. Thus, it is somewhat inevitable that the cases (and texts) on escape and rescue-as well as the punishment of jailers for letting prisoners escape — tend to be concerned with these instances.

The relative ease in which it was possible to escape from prison applies all the more to the small rooms or lockups utilised by villages, towns and boroughs by their constables and headboroughs (also called tithingmen). ${ }^{39}$

\section{Concept of 'Escape' In Early Times}

Pugh stated that:

In the middle ages the word 'escape' covered a multitude of different activities. It might be used where a prisoner broke out of prison or where he simply walked out. It might signify that a sheriff, gaoler, or other officer had corruptly allowed a prisoner to purchase his release, or that a prisoner who was being escorted to prison by a tithing, township, or village constable eluded the vigilance of the escort. Eventually it could even be used where a man arrested at the suit of a party was subjected to a form of detention too mild to achieve the coercive aims of his antagonist-at-law. These various forms of 'escaping', if proved against the prisoner or his keeper, usually brought punishment to one or other or to both. To fix the blame and to settle the punishment occupied much time and thought and resulted in the end in the erection of a gigantic mound of legal learning. 40

Pugh also notes that references to escape can be traced back as early as the Pipe Roll of $1130 .^{41}$ He cites some examples. In 1229-31, no less than 31 thieves escaped from Winchester prison. ${ }^{42}$ And, in 1275,19 persons broke out of Newgate prison. ${ }^{43}$ Further, there were rescues - such as in 1268 when armed men broke into the bishop of Lincoln's prison to rescue a man. ${ }^{44}$

In conclusion, early on, 'escape' involved not only a prisoner escaping from a prison. It included where a person freed himself from the arrest of a constable (headborough etc.) or from his lock-up (police station). Also, where a prisoner became free as a result of the wilful assistance-or negligence-of his jailer or a constable.

\section{Punishment Prior to 1295}

In early times it is likely that escaped prisoners often suffered immediate 'rough' justice and, therefore, a case never came before a court in respect of their escaping. ${ }^{45}$ Also, it seems clear that-prior to 1295 - the common law provided that 'breaking prison' (that is, escaping using force) was a felony. Thus, Bracton, On the Laws and Customs of England written c.1240, stated:

When they have been confined to prison because of the nature of their crime, they conspire to break their chains and break prison and escape, they are to be punished more severely than the reason for their consignment to prison demands, that is by the supreme penalty [i.e. death], even if they are found innocent of the crime for which they were imprisoned. ${ }^{46}$

\footnotetext{
more professional (often, they comprised ex-military personnel paid for by the county, as opposed to jailers operating pursuant to a franchise who were paid pursuant to fees exacted from prisoners). See also Bellamy, n 11, pp 177, 178.

${ }^{39}$ Halsbury, Statutes of England, vol 33(2), preliminary note to the Act, notes that the earliest form of police organization seemed to have been a local association of persons who - as the king's subjects - became sureties for one another's keeping the peace. These associations elected principal men called headboroughs, borsholders or tithingmen who were responsible for maintaining order in the association. DM Walker, The Oxford Companion to Law (Oxford, 1980) (definition of headborough). 'The chief of the 10 men who comprised a frankpledge (qv), elected by the court leet with the responsibility for the keeping of order in the area for which he was elected. They were gradually replaced by petty and parish constables.' See also Halsbury, n 18, vol 36(1), para 101. Hale, n 4, vol 2, p 96 noted that the authority of the tithingmen, headboroughs and borsholders were much the same as that of the contstable (none of the former positions now exist). See also Penal Reform in England (Macmillan \& Co, 1946), ch 4 (the English police system).

${ }^{40}$ Pugh, n 11, p 218. He cites, Hale, n 4.

${ }^{41}$ Ibid. Cf. The escape of Flambard in 1100, n 24.

${ }^{42}$ Ibid, p 219. See also Harding, n 11, p 22.

${ }^{43}$ Ibid, p 220.

${ }^{44}$ Ibid, p 222. See also rescues from the Tower of London in 1312 and 1325. Ibid, pp 222-3.

${ }^{45}$ Pugh, n 11, p 227 mentions escaped prisoners being beheaded on the spot in 1293, 1315 and 1324. Bellamy, n 11, p 178 'Until the middle of the fourteenth century a prisoner who was originally suspect of felony might, on recapture, be executed without proper trial.' See also JW Jeudwine, Tort Crime and Police Law (London, 1917), p 156 (lynch law for escapees).

${ }^{46} \mathrm{H}$ Bracton (trans Thorne), On the Laws and Customs of England c.1240 (Cambridge UP, 1968-76), vol 1, p 350. Bracton is now online, see bracton.law.harvard.edu. Pugh, n 11, p 228 'It was not altogether an unreasonable attitude since, in certain circumstances at least, the escaper, by the very act of escaping, admitted his own guilt and, if a suspected felon, might be expected to suffer a felon's fate.' He cites examples in 1208 and 1221.
} 
This was draconian and it seems to have applied regardless of whether a person was in prison on account of a crime or a civil matter. ${ }^{47}$ Also, whenever a person was in lawful custody-whether that was in prison or not. ${ }^{48}$ One suspects the (eventual) source of this was Roman law since Callistratus, a Roman jurist, in book 6 his Judicial Examinations, declared:

Of those who, after being lodged in prison, conspire to smash their fetters and break out of jail, punishment is to be imposed over and beyond that due for the offence for which they were lodged as accused; and even though they be found innocent of the charge for which they were flung in jail, yet they should [still] be punished: but those who expressed their conspiracy should receive a lighter penalty. 49

Britton, writing c. 1290, re-iterated the punishment of death for prison breach:

We will that a prison be accounted a place limited by us within certain bounds for the keeping of the bodies of men, which bounds we forbid on pain of death any one to pass with a felonious intent of escaping; and if any one having such intent is taken, and is attainted of compassing that felonious intent, let him receive judgment of death. ${ }^{50}$

However, Britton asserted that it was not a felony for a prisoner to escape from a franchise prison. ${ }^{51}$ This appears to also be the opinion of the author of The Mirror of Justices (c.1290). ${ }^{52}$ And, if a prisoner escaped by being let out by his jailer - either voluntarily or by negligence - it seems the prisoner was not held responsible and, thus, was not punished as a felon. He had 'gone out' not 'broken out'. 53 As to the jailer:

- In the case of breaking out, Britton stated that the jailer should be fined $100 s .{ }^{54}$ However, if the jailer was found guilty of having consented to the breaking out (i.e. it was voluntary), the punishment was death. ${ }^{55}$ That said, Pugh noted there seemed to be few instances where the same was inflicted with all its rigour. ${ }^{56}$ Rather, in the early $12^{\text {th }}$ century, at least, the jailer usually incurred a heavy fine. Sometimes, he also lost his office, was imprisoned or outlawed. ${ }^{57}$

Coke (published in 1641), commenting on Bracton and Britton, states what was the probable position, pre-1295:

It appeareth by our ancient authors of the law, that if a prisoner, whatsoever the cause was for which he was committed [whether criminal or civil], had broken the king's prison and escaped out, it was felony; because interest reip. ut carceres sint in tuto: [it is in the State's interest that prisons should be secure] but yet it must have been an actual breaking of the prison; for if the door had been open, and he had gone out, or if others without his privity [knowledge] had broken open the prison door etc. and he goes

\footnotetext{
${ }^{47}$ The writer of The Mirror of Justices (c. 1290), Selden Society, vol 7, p 156 complained 'It is an abuse that an escape from prison or breach of gaol is accounted a mortal sin [felony], for this usage is warranted by no law, and does not obtain anywhere save in this realm and in France, and one is warranted by the law of nature [in attempting to escape].' See also W Eden, Principles of Penal Law (printed for B White, 1771), p 204.

${ }^{48}$ Hawkins, n 4, vol 2, p 123 'And first as to prison breaches, as they stood by the common law; it seems the better opinion, that all such offences were felonies, if the party were lawfully in prison for any cause whatsoever, whether criminal or civil, and whether he were actually in the walls of a prison, or only in the stocks, or in the custody of any person who had lawfully arrested him; and it seems not to have been any way material whether the prison did belong to the king, or to the lord of a franchise...' Hawkins may be incorrect in this in respect of franchise prisons (private prisons), see ns 51 \& 52 re Britton and the Mirror.

${ }^{49}$ See A Watson, Digest of Justinian (trans. University of Pennsylvania Press, 1985), vol 4, 48.3.13. Bracton's formulation is close to this, suggesting he may have had regard to this passage.

${ }^{50}$ Britton (ed FM Nichols, John Byrne, 1901), p 37. Fleta (c.1290), Selden Society, vol 72, p 68 who makes it even more draconian 'If a charge of escape of thieves and prison-breaking is brought, not only will the prison-breakers and they who removed their fetters be held liable, but all others found in the goal, even though they are blameless of any fault, except there by any [among them] who discovered the conspiracy of the prison-breakers and cried out or otherwise hindered [the escape] to the best of his ability.' Pugh, n 11, p 228 'all the evidence contributes to the view that throughout the greater part of the thirteenth century prison-breaking was a felony in itself, and by Westminster (1275) [ie. the Statute of Westminster the First 1275, c 13] it was numbered among irrepleviable offences.'

${ }_{51}$ Ibid 'to escape from the prison of another is no felony.' See also Pugh, n 11, p 93, 230.

${ }^{52}$ Mirror, n 47, p 52 'Every common prison is a gaol, and only the king has the keeping of it. Every other man's prison is private, and from this anyone may escape who can, provided he do not other trespass in his escape.'

${ }^{53}$ Pugh, n 11, p 230 'If the door stood open through the negligence of the gaoler or was forced open by the activities of other prisoners or a mob without, the prisoner himself was exonerated. He had 'gone out' not 'broken out', and any culpability was transferred from him to his rescuers or keepers.' See also the statement of Coke in the text to $n 58$.

${ }^{54}$ Britton, n 50, p 37. Also 'If the prisoner was in the custody of any one claiming the wardenship in fee, let the franchise be seized into our hands...If any prisoner escape from the custody of a township, let the township be in our mercy in the eyre of the justices, according to the custom of the country; and if from the custody of a private person, let such person be amerced...'. See also the Mirror, n 47, p 151 (amercements re escape).

${ }^{55} \mathrm{Ibid}$, 'If any gaoler be suspected of having consented to the escape, let him be taken and indicted for consenting to the felony; and if he be found guilty of consenting, let him have judgment of death.'

${ }^{56}$ Pugh, n 11, p 234.

${ }^{57}$ Ibid, p 232. See also pp 234-5.
} 
out, and escapes, or if the gaoler himself had let him out; in these cases it had been no felony, because the prisoners did not actually break the prison. And so it is of a felon that is under custody of the king's officer (which is an imprisonment in law) and divers men do refuse or take him by force out of the custody of the king's officer, this is felony in them all by the common law. ${ }^{58}$ (spelling modernised).

Coke also noted that there was no escape (or breaking out) when a prisoner fled the prison due to fire or to safeguard his life. ${ }^{59}$ Nor in the case of false imprisonment ${ }^{60}$ or where the warrant for committal was unlawful. ${ }^{61}$ Further, one suspects that any escape (or rescue) from the custody of the constable, headborough or sheriff may also have been treated with less severity, pre-1295. That is, it was not the same as in the case of a prison. ${ }^{62}$

In conclusion - prior to 1295-it seems likely that escape, prison breach or rescue from a royal prison-whether the prisoner was in prison for a criminal, or a civil, offence-merited death. ${ }^{63}$ However, where the same was from a private prison - or in the case of false imprisonment or where the warrant for committal was unlawfulthis severity did not apply. Also, where the escape, prison breach or rescue was from the custody of a constable, sheriff or headborough the punishment may have been less. So too where a jailer negligently-as opposed to voluntarily - let a prisoner escape. It is unlikely the jailer suffered death as a result.

\section{Punishment after 1295}

The punishment of death for a prisoner who may have been incarcerated only for a minor criminal, or a civil, offence was unduly harsh. As a result, the Statutum De Frangentibus Prisonam 1295 (repealed in 1948) ${ }^{64}$ clarified that it was only a felony to break prison (i.e. to escape using force) if the person involved had been committed for felony. It stated: ${ }^{65}$

Concerning prisoners which break prison, our lord the king [Edward I, 1272-1307] willeth and commandeth, that none from henceforth that breaketh prison shall have judgment of life or member for breaking of prison only, except the cause for which he was taken and imprisoned did require such judgment, if he had been convict thereon according to the law and custom of the realm, albeit in times past it hath been used otherwise. ${ }^{66}$

In the case of rescue, the position did not differ from that of prison breach. It was a felony to rescue a felon (where he participated). Coke stated:

And so does Hussey chief justice [Huse CJKB] report the case, that in the reign of Edward IV [1461-83] when he was attorney, it was resolved by Billing chief justice, Choke, and the judges, that the rescous [rescue] of a felon, to take him out of custody and prison, was always felony by the common law, but of the prisoner himself it was not, etc. which must of necessity be intended, when other men did rescue him, or break open the prison without his privity [knowledge], and these words in the report (tanque lestatute fuit fait de frangentibus prisonam) ought to be omitted. ${ }^{67}$

Coke's reference to Huse CJ is to a case before the Exchequer Chamber in $1468 .{ }^{68}$ A convicted felon, while being taken to the gallows, was rescued from the sheriff's custody by others using force, and taken to sanctuary. It was held this was a felony in the rescuers. Also, that all were liable as principals. In this decision, Huse CJKB recalled a case when he was Attorney-General where the justices said that a rescue from prison was a felony at common law, but that a rescue from the person of the under-sheriff or sheriff was not a felony until the statute of

\footnotetext{
${ }^{58}$ Coke, n 13, vol 2, p 588 .

${ }^{59}$ Ibid, p 589.

${ }^{60}$ Ibid, p 590

${ }^{61}$ Ibid, p 591 'if the warrant be not lawful, if the gaoler suffer such a prisoner to escape voluntarily, it is no felony in him.'

${ }^{62}$ In other words, the law recognised early on that prison escape was more serious than the escape from the custody of a sheriff, constable or private person.

${ }^{63}$ Russell (writing in 1964), n 4, p 330 'breach of prison, or even conspiracy to break it, is felony at common law, for whatever cause, criminal or civil, the party was lawfully imprisoned; and whether he was actually within the walls of the prison or only in the stocks, or in the custody of any person who had lawfully arrested him.' Dalton, n 13 (writing in 1619) 'Breaking of prison (before the statute De Frangentibus Prisonam, made 1 Edw 2) was felony by the common law, for what cause soever he were in prison, yea though hee had beene imprisoned but for a trespasse.'

${ }^{64}$ It was repealed by the Statute Law Reform Act 1948.

${ }^{65} 23$ Edw 1.

${ }^{66}$ This statute was analysed in detail in Coke, n 13, vol 2, pp 588-92. Pugh, n 11, p 228 'a statute of 1295, which declared that none should have judgment of life or members merely for the offence of breaking prison...Such punishment was only to be inflicted if it was the one appropriate to the offence with which the prisoner had been charged.' Hale, n 4, p 611 'If a felony be made by Act of Parliament subsequent to $1 \mathrm{E} 2$ [the statute of 1295] and the person be committed for such a felony and break prison, yet this is felony.'

${ }^{67}$ Coke, $\mathrm{n} 13$, vol 2, p 588. See also Hale, n 4, p 607.

${ }^{68} 1$ Hen 7 pl 2 fo 6a (1486). See also Seipp 1486.002 (1486, Exchequer Chamber). Translations of many of the 22,000 cases in the Yearbooks have been published online by professor David Seipp in the form of an Index, www.bu.edu/law/faculty/scholarship/yearbooks)
} 
Statutum De Frangentibus Prisonam 1295 (see above). ${ }^{69}$ Thus, after 1295, in the case where a person was committed for felony, it was a felony for him to escape or commit prison breach. So too, it was a felony in the case of any rescuers. ${ }^{70}$ What though of the jailer?

- Generally, it seems that jailers were fined in the case where they negligently permitted an escape, prison breach or rescue. Probably, they also often lost their office. It may be noted that the Statute of Escapes (1504) laid down a tariff of fines-including fines for the escape of a suspect felon charged with a crime less serious than murder. As Pugh noted, the effect of this Act seemed to blur the distinction between 'negligent' and 'voluntary' escapes. ${ }^{71}$ By the time Hale wrote (in the 1640's) he stated authoritatively that 'negligent escapes of felons are not felony, but punishable by fine upon the parties, that suffer them. ${ }^{72}$ Hale also thought that prison breach was negligent escape on the part of the jailer since the jail should have been sufficiently secure to prevent this. ${ }^{73}$ Further, it seems that jailers were often pardoned (which pardon they usually purchased) in the case where they did not actively connive at the escape (that is, it was not a voluntary escape) ${ }^{74}$

- As to a voluntary escape, Coke (published 1641) said that there was no felony in the jailer unless the prisoner was under custody by lawful warrant expressing the offence and there must be a felony at the time of the escape. ${ }^{75}$ That said, one suspects that - even in this case-jailers were not often executed. If they were, who would want to risk his life in the uncertain area of a judge determining whether a prisoner had escaped by reason of the jailer's negligence or wilfulness? Thus, the law on this, for jailers, was really in terrorem.

Finally, in Elizabethan times, escape from arrest could result in additional penalties, by virtue of proclamation. $^{76}$

In conclusion, after 1295, it seems that escape, prison breach or rescue from a prison-when the prisoner was committed for the same-merited death. However, in other cases, it is likely that imprisonment and/or a fine was the result. ${ }^{77}$ A jailer (or sheriff or constable) may also have lost office where he intentionally, or negligently, permitted an escape.

\section{Punishment in The Case of High Treason}

An exception was made in the case of high treason. Here the punishment was particularly gruesome- drawing, hanging and quartering. ${ }^{78}$ Thus, it is not unexpected that a prisoner would seek to break out of prison, whether before his trial or - more especially — after he knew the verdict.

\footnotetext{
${ }^{69}$ This case may have been 1473.004 = Pasch. 13 Edw 4, pl 4, fo 8b-9a. See also Select Cases in the Exchequer Chamber, SS, vol 64, p 34, case 13 (note on the status of the escaped prisoner). Billing was Chief Justice of the King's Bench from 1469-81. Choke was justice of the Common Pleas from 1461-83.

${ }^{70}$ Hale, n 4, p 606 'Rescue of a person imprisoned for felony is also felony by the common law.' Hale noted that the person must have been in custody for felony (or suspicion of felony) or under arrest for felony. Ibid.

${ }^{71}$ See 19 Hen VII c 10 (1503-4)(of Voluntary and Negligent Escapes, also called the Statute of Escapes). Pugh, n 11, p 237 'The effect of the statute seems to be to blur the distinction between 'voluntary' and 'negligent' escapes, with both of which, according to its title, it purports to deal, and to treat most escapes as 'negligent'. In the interests of ensuring that escapes if proved do not go unpunished altogether, it relaxes the serious consequences of corrupt participation on the keeper's part.' Sometimes, Parliament specified a determined fine (often very high) if a jailer were to let an important prisoner escape. Ibid, pp 240-1. For the responsibility of the jailer for an escaped debtor's debt, see Pugh, $n$ $11, \mathrm{pp} 242-4$.

${ }^{72}$ Hale, n 4, p 600.

${ }^{73} \mathrm{Ibid}, \mathrm{p} 601$. This also explains (perhaps) why judges in earlier times had no problem with prisoners (especially those charged with treason) being loaded with irons, in order to forestall escape. It was to protect the jailers.

${ }^{74}$ Pugh, n 11, p 245-8. General pardons for escapes were also granted. See, for example, Proclamation Announcing Coronation Pardon of Mary of 24 October 1553 ('every kind of escapes and evasions, voluntary as well as involuntary or negligent, of whatsoever criminals, murderers, felons, and suspects of the same.'). See PL Hughes \& JF Larkin, Tudor Royal Proclamations (Yale UP, 1969), vol 2, p 13. See also, p 104 (Elizabeth I, 15 January, 1559) and 14 \& 15 Henry VIII c 16 (1523)(King's General Pardon). See also Bellamy, n 11, p 194 (purchase of pardons).

${ }^{75}$ Coke, $\mathrm{n} \mathrm{13,} \mathrm{vol} \mathrm{3,} \mathrm{p} 69$ 'There must be a felony done at the time of the escape: for a relation which is but a fiction of law, shall never make a man a felon, as likewise there it appeareth.' Coke refers to Staunford, n 12, book 1, cap 26 (voluntary escape). See also Coke, n 13, vol 2, p 590.

${ }^{76}$ For example, proclamation of 21 March 1565 of Elizabeth I (1588-1602) providing Penalties for Resisting Arrest (persons required to obey and yield themselves to the arrests and attachments of all mayors, sheriffs, bailiffs, sergeants, and other ministers 'without refusal, rescues, or resistance' on pain of being committed to prison and to be severely chastised and punished for the contempt, on top of the punishment for the offence). See Hughes, n 74, vol 2, pp 260-1. Also, vol 3, pp 82-3 (proclamation prohibiting unlawful assembly under martial law of 20 June 1591) \& p 143 (Ibid, 4 July 1595).

${ }^{77}$ For example, The Calendar of Plea and Memoranda Rolls of the City of London 1323-1364 (Cambrige UP, 1926), p 267 cites the bailiff of Smithfield in 1364 being committed to Newgate for a year and a day for rescuing a man from the Mayor's doorkeeper who was being taken to Newgate prison for brawling. See also Calendar of Select Pleas and Memoranda of the City of London 1381-1412 (Cambridge UP, 1932), pp 92-8, 113-6, 179,223-4, 233 (actions against sheriffs and jailers re escape of prisoners).

${ }^{78}$ See $n 3$.
} 
- Prior to the Treason Act 1351, there was uncertainty as to what comprised treason and what did not. Presumably, escape, prison break or rescue in these cases was, at least, a felony, if not meriting the same punishment as for treason; ${ }^{79}$

- The Treason Act 1351 laid down the various crimes which comprised high treason ('HT') —although a number of these (and more) were likely treason prior to this Act. Then, in 1423, an Act (repealed 1863) ${ }^{80}$ made it HT for a person committed for HT to break out of prison.

Prior to this Act of 1423 there had been a famous case of prison breach in $1413^{81}$ —albeit, Oldcastle was not condemned for such, nor for treason but for heresy (the original charge). As to what led to the Act of 1423, the position is not clear whether it was the result of the circumstances relating to Thomas Exeter (Excestre) $)^{82}$ and/or Sir John Mortimer. Probably, the latter, in particular, influenced the Act of $1423 .{ }^{83}$ The preamble to this Act also making it clear that its purpose was to clarify an otherwise uncertain position. ${ }^{84}$

- In 1421, Exeter-who it is said was committed to prison on suspicion of treason ${ }^{85}$ - escaped from prison prior to trial. ${ }^{86}$ Re-taken on a charge of theft, he was indicted not for this but for prison breach. Found guilty he suffered, in 1423, the same punishment as for treason. ${ }^{87}$ I have said 'it is said' since the commentary to the note in the Selden Society reports indicates this. However, the note itself suggests that Exeter was actually in prison for a felony ${ }^{88}$ (as did Dyer, in his notebook in 1555). ${ }^{89}$ While in prison Exeter escaped. At the same time, he rescued other prisoners there for treason (it seems he knew

\footnotetext{
${ }^{79}$ In 1323, the younger Roger Mortimer escaped from the Tower of London. On 1 August 1323, with the connivance of Gerard de Alspaye, (sub-lieutenant of the Tower who had custody of him) and after the guards and Stephen de Segrave (the constable of the Tower) had been drugged, Mortimer escaped and fled to France. See ODNB, n 24, Roger Mortimer, 1st Earl of March (1287-1330). See also Pugh, n 11, pp 162, 221-2. As to punishment, it seems that Segrave (Seagrave) was held responsible. In May 1324, he and his father were amerced by Edward II (1307-27) for the payment of 10,000 marks in order to obtain pardon for this misdemenour. See generally, I Mortimer, The Greatest Traitor (Pimlico, 2004), pp 129-34.

${ }^{80} 2$ Hen 6 c 21. It was repealed by the Statute Law Repeals Act 1863. See also Coke, n 13, vol 2, p 589.

${ }^{81}$ In 1413, Sir John Oldcastle (commonly styled Lord Cobham, as a result of his marriage with the grand-daughter of the last lord) was condemned as a heretic. He subsequently escaped from the Tower of London. Re-captured, he was condemned and burnt as a heretic. See ODNB, n 24, he 'escaped on 19 October, with the assistance of some London allies.' The Chronica Maiora of Thomas Walsingham (13761422) (trans D Preest, The Boydell Press, 2005), p 393, n 2 says that assistance was provided by a Warrington franciscan, a Shropshire scrivener and a London parchment-maker (the latter, it seems, was subsequently executed in 1416 for treason for rescue, see HT Riley, Memorials of London and London Life (Longmans, 1868), pp. 641-2). In 1417, Oldcastle was captured in Wales, brought to London and taken before Parliament. He denied their jurisdiction over him, affirming that the deposed Richard II (1377-99) was still alive. On this, he was condemned without a further hearing and burned to death as a heretic. See Preest, pp 427-8. Also, EF Jacob, The Fifteenth Century 1399-1485 (Oxford, Clarendon Press, 1961), p 130.

${ }^{82}$ The case of Exeter was one of prison breach, whereas the Act of 1423 refers to 'escape voluntarily'.

${ }^{83}$ JG Bellamy, The Law of Treason in England and Wales in the Later Middle Ages (Cambridge UP, 1970), pp 130-1 thought so. He also noted that, in July 1392, assisting a prisoner convicted of treason to escape from York gaol was called felony, p 131. However, by the time of the 1414 Parliament, a porter at the Tower of London was drawn, hung and beheaded for 'consenting' to one 'that brake out of the Tower named Whitlocke'. That said, what Whitlock was in prison for is not wholly clear.

${ }^{84}$ The 1423 Act (2 Hen VI) c 21, preamble, states 'Forasmuch as in the time of [Edward III] at his Parliament holden at Westminster; it was declared by statute what things ought to be called treason [this is a reference to the Treason Act 1351], among which, if a man was indicted, appealed, or taken for suspicion of high treason, and for that cause committed and detained in the king's prison, and afterwards such prisoner escaped out of the king's prison, declaration hath not been made before this time, whether such escape should be adjudged treason or not.'

${ }^{85}$ YB 1 Hen VI, Selden Society Reports ('SS'), vol 50, pp xxvi-ii. The treason was alleged to have been committed in 1414-6. He and a man named Abro White had spied out the counsel of the king at Nottingham and elsewhere, to send information to the king's enemies in Ireland. See, pp xxvii, 69-76. Cf. p 69 the note suggests that Excestre was outlawed for felony and was not in prison for treason, see $\mathrm{n} n 88$.

${ }^{86}$ In 1422, knives, files and hatchets were smuggled into the prison (the Marshalsea) which Exeter and other prisoners used to break their bonds and escape.

${ }^{87}$ Pugh, n 11, p 229. See also Seipp, n 68, 1422.056ss (referring 1 Hen VI pl 22 fo 5b). It says that Excestre was drawn and hanged (fuit traine et auxy pendu). Pulton (writing in 1609) thought this was petty treason, see $\mathrm{n} 12$, pp 111 'It is petit treason if a man outlawed of felony, and imprisoned in the k[ing's] bench, be attainted for breaking of prison, and letting at liberty such persons as were there imprisoned for treason.'(spelling modernised). Also, p 148 'If a man imprisoned for felony, doth break the prison, and let escape a prisoner that is in prison for treason, this is petit treason in him that did break the prison.' See also Fitzherbert (in 1584), n 12, p 30.

${ }^{88}$ See SS, $n$ 85, p 69. It says 'A man was outlawed for felony and was imprisoned in the king's bench. And he was indicted in the king's bench [on an indictment] that he broke the prison, and knowing [sachaunt] that certain persons were prisoners in the same prison for treason, he led them out. And for this he was arraigned, and he pleaded not guilty: and he was found guilty: and he was adjudged by all the justices a traitor, and he was drawn and hanged etc. Note this.' Also 'A man outlawed for felony is imprisoned in the king's bench [on a charge] that he had broken the prison, knowing that prisoners were in it. And it is adjudged treason by all the justices there. And he was drawn and hanged.' ${ }^{89}$ Dyer in Dyer's Reports, SS, n 85, vol 110, p 406 refers to a felony. He noted (1555) 'One Bennet was attainted of high treason, for counterfeiting coin, and was wilfully allowed to escape by the gaoler. The gaoler is índicted for this as a traitor. Should the indictment say 'knowing Bennet to be attainted...' as in 1 Hen VI? (there someone was outlawed for felony and imprisoned in the king's bench broke the prison, knowing the prisoners to be there for treason, and brought them out, and this was adjudged treason [he refers to YB Mich 1 Hen VI, fo 5, pl 22-Exeter's Case]. Afterwards, at the next assizes, the gaoler was acquitted of voluntary escape.' See also The Reports of William
} Dalison, SS, vol 124, p 83 (refers to same case). 
this). This would seem a better interpretation viz. that Exeter was executed for treason in rescuing prisoners in prison for the same, and not for his own escape, ${ }^{90}$

- In 1421, Sir John Mortimer was imprisoned in the Tower of London on suspicion of treason. What the treason was, is unclear. However, it was likely that of conspiring to kill Henry VI (1421-6, 70-1) - a treason under the Treason Act 1351 - and seek the throne in his stead. ${ }^{91}$ Mortimer escaped in 1422 . He was re-captured. He escaped again from the Tower of London some time after November 1423. Recaptured once more, he was charged with prison breach in 1424 before Parliament and executed for treason (the 1423 Act came into effect on 20 October 1423). ${ }^{92}$ Thus, this seems to be an example of it being treason to commit prison breach when committed to prison on suspicion of treason, in accordance with the 1423 Act.

In the case of Mortimer, it may be suspected that he was tried by Parliament after the Act was passed so that he could prosecuted under it. ${ }^{93}$ The gravamen of the 1423 Act provided that persons committed for treason, who escaped, were to be considered as convicted. Thus, it stated:

if any person be indicted, appealed, or taken for suspicion of high treason, as aforesaid, and be committed and detained in the king's prison for that cause, and escape voluntarily out of the said prison, that such escape be adjudged and declared treason, if such person be thereof duly attainted, according to the law of this land. ${ }^{94}$

In conclusion, to escape from prison when committed for HT, was HT under the Act of 1423 (now repealed). Since prison breach, rescue and where a jailer voluntarily permits a person committed for treason to escapeare as (if not more) serious than escape, after the Act of 1423, they would also incur the penalty of HT if the prisoner who escaped or was freed was committed for $H T^{95}$

\section{Escape etc. In the Time of Blackstone}

By the time Hale wrote his History of the Pleas of the Crown in the 1640's the law on escape, prison breach and rescue had become very convoluted and obscure. So too, when Hawkins wrote his Treatise of the Pleas of the Crown in 1716. Both texts are fairly impenetrable on this. However, Blackstone, writing his Commentaries on the Laws on England in 1768, was more succinct and clear ${ }^{96}$ (given this, it is a pity he is not referred to more often than Hawkins). ${ }^{97}$ Blackstone considered the position from the civil—and then the criminal—sphere, which helped clarify matters. Thus, in the civil sphere, when considering the writ of capias ad satisfaciendum - a form

\footnotetext{
${ }^{90}$ This clearly seems to be the view of Hawkins, n 4, p 127 'a person committed for high treason becomes guilty of felony only, and not of high treason, by breaking the prison and escaping singly, without letting out any other prisoner; for that no offence is to be construed high treason, which is not either within the purview of [the Treason Act 1351, still extant] or of some subsequent statute relating to treason; but if other persons committed also for high treason escape together with him, and his intention in breaking the prison were to favour their escape as well as his own, he seems to be guilty of high treason in respect of their escape, for that there are no accessories in high treason; and such assistance given to persons committed for felony, will make him who gives it an accessory to the felony, and by the same reason a principal in the case of high treason.' See also p 140. Also, Pugh, n 11, p 231. Pugh says that the man who helped Exeter escape was executed as a traitor (see also $\mathrm{n}$ 81). However, this is not stated in YB 1 Hen VI, SS, n 85 vol 50, pp xxvi-ii.

${ }^{91}$ The treason seems to have been to aspire to the throne as heir of the Earl of March, see B Wolffe, Henry VI (Eyre Methuen, 1981), pp 34-5 Also, Bellamy, n 83, p 130. See also YB 1 Hen VI, SS, n 85, vol 50, pp xxv-vi. Mortimer escaped from the Tower in 1422 in the company of Thomas Payne (Payn), secretary to Sir John Oldcastle. He was re-taken to the Tower before November1423. It is not wholly clear whether the Act of 1423 was passed with reference to his escape - to clarify that it was treason to escape when held for treason. However, it may be Mortimer was tried for treason prior to the Act and then escaped after it, such that its terms applied. See, $\mathrm{p}$ xxvi. See also Bellamy, $\mathrm{n} 83$, pp 130, 172-3, 195 and Bellamy, n 11, p 165. This case is analysed in detail in The Parliament Rolls of Medieval England (Scholarly Digital Editions, CD) (where it is asserted in the commentary that the Act was passed to deal with Mortimer). See also E Powell, The Strange Death of Sir John Mortimer: Politics and the Law of Treason in Lancastrian England in Rulers and Ruled in Late Medieval England. Essays presented to Gerald Harriss ed R Archer \& S Walker (London, 1995), pp 83-97. See also 1 ST 266 (it thought that the first escape of Mortimer was the one for which he was tried and executed).

${ }^{92}$ Ibid. See also YB 1 Hen VI, SS, n 85, vol 50, pp xxvi-ii and Coke, n 13, vol 2, p 589.

${ }_{93}$ The case of Exeter, on any account, was one of prison breach, whereas the Act of 1423 refers to 'escape voluntarily'.

${ }^{94} 2$ Hen VI c 21 (1423). See also 19 Hen VII c 10 (1503)(Of Voluntary and Negligent Escapes, rep. 1856) and 14 Eliz c 2 (1572) (Act against such as shall Conspire or Practice the Enlargement of any Prisoner committed for High Treason, rep 1863). See also McBain, n 3.

${ }^{95}$ The 1414 execution of a jailer for voluntary escape mentioned by Bellamy (see $n$ 83) seems good authority for this. Hale, $\mathrm{n} 4$, p 590 'A voluntary escape is when any person having a felon lawfully in his custody voluntarily permits him to escape from it or to go at large, and this is...treason in case the person be imprisoned for treason.' Cf. p 596 'If the prisoner be rescued, or rescue himself [ie. escape or commit prison breach] against the will of him, that hath him in custody, this is no voluntary escape, nor is the gaoler etc punishable for the same.'

${ }_{96}$ In part, this was helped by the fact that there were few franchise prisons left. For the position mid-17th century and indictments, see W Stubbs \& G Talmash, The Crown Circuit Companion (printed for H Lintot, 1749), pp 220-3 (indictments for a constable negligently permitting escape re a felony and a misdemeanor, also against a jailer for permitting a prisoner to escape).

${ }^{97}$ In the case of Hale, $\mathrm{n} 4$, his text was published in 1736 . However, being written in the 1640 's (and not corrected by him) it is of less accuracy than that of Hawkins. The best editions for Hawkins generally are those of 1739 (3rd ed) and 1824 (last ed).
} 
of execution against the body of the debtor until satisfaction was made for the debt, costs and damages ${ }^{98}$ - he stated:

Escapes are either voluntary, or negligent. Voluntary are such as are by the express consent of the keeper, after which he can never re-take his prisoner again (though the plaintiff may re-take him at any time) but the sheriff must answer for the debt. Negligent escapes are where the prisoner escapes without his keeper's knowledge or consent; and then upon fresh pursuit the defendant may re-taken, and the sheriff shall be excused, if he has him again before any action brought against himself for the escape. A rescue of a prisoner in execution, either going to gaol or in gaol, or a breach of prison, will not excuse the sheriff from being guilty of and answering for the escape; for he ought to have sufficient force to keep him, seeing he may command the power of the county [ie. the posse comitatus]. ${ }^{99}$

In the criminal sphere, Blackstone (writing in 1769) stated as to escape:

An escape of a person arrested upon criminal process, by eluding the vigilance of his keepers before he is put in hold, is also an offence against public justice, and the party himself is punishable by fine or imprisonment. 100

But the officer permitting such escape, either by negligence or connivance, is much more culpable than the prisoner; the natural desire of liberty pleading strongly in his behalf, though he ought in strictness of law to submit himself quietly to custody, till cleared by the due course of justice. Officers therefore, who, after arrest, negligently permit a felon to escape, are also punished by fine; ${ }^{101}$ but voluntary escapes, by consent and connivance of the officer, are a much more serious offence: for it is generally agreed that such escapes amount to the same kind of offence, and are punishable in the same degree, as the offence for which the prisoner is guilty, and for which he is in custody, whether treason, felony or trespass. And this, whether he were actually committed to gaol, or only under bare arrest. ${ }^{102}$ But the officer cannot be thus punished, till the original delinquent is actually found guilty or convicted, by verdict, confession, or outlawry, of the crime for which he was so committed or arrested: otherwise it might happen, that the officer might be punished for treason or felony, and the person arrested and escaping might turn out to be an innocent man. But, before the conviction of the principal party, the officer thus neglecting his duty may be fined and imprisoned for a misdemeanour. ${ }^{103}$ (wording divided for ease of reference).

As to breach of prison, Blackstone states:

Breach of prison by the offender himself, when committed for any cause, was felony at the common law: or even conspiring to break it. But this severity was mitigated by the statute de frangentibus prisonam, 1 Edw II [ see 5] which enacts, that no person shall have judgment of life or member, for breaking prison, unless committed for some capital offence. So that to break prison, when lawfully committed for any treason or felony, remains still felony as at the common law; and to break prison, when lawfully confined upon any other inferior charge, is still punishable as a high misdemeanour by fine and imprisonment. For the statute, which ordains that such offence shall be no longer capital, never meant to exempt it entirely from every degree of punishment. ${ }^{104}$

As to rescue, Blackstone states:

Rescue is the forcibly freeing another from an arrest or imprisonment; and is always the same offence in the stranger so rescuing, as it would have been in the party himself to have broken prison. ${ }^{105} \mathrm{~A}$ rescue therefore of one apprehended for felony, is felony; for treason, treason; and for a misdemeanour, a misdemeanour also. But here, as upon voluntary escapes, the principal must first be attainted before the rescuer can be punished: and for the same reason; because perhaps in fact it may turn out that there has been no offence committed. ${ }^{106}$

\footnotetext{
${ }^{98}$ Blackstone, n 16, vol 3, p 415 'The writ of capias ad satisfaciendum is an execution of the highest nature, in as much as it deprives a man of his liberty, till he makes the satisfaction awarded.'

${ }^{99}$ Ibid, pp 415-6. See also Hawkins, n 4, book 2, ch 21.

${ }^{100}$ Ibid, vol, 4, p 130. He cites Hawkins, n 4, book 2, p 122.

${ }^{101}$ Ibid. He cites Hale, n 4, vol 1, p 600 (ch 52, negligent escapes).

102 Ibid. He cites Hale, n 4, vol 1, p 590 (ch 51, voluntary escapes) and Hawkins, n 4, book 2, p 134.

${ }^{103}$ Ibid. He cites Hale, n 4, vol 1, pp 588-9 (ch 51, voluntary escapes) and Hawkins, n 4, book 2, pp 134-5.

${ }^{104}$ Ibid, pp 130-1. He cites Hawkins, n 4, book 2, p 128.

${ }^{105}$ Ibid, p 131. See also Hawkins n 4, book 2, pp 139-40.

${ }^{106}$ He cites Hale, n 4, vol 1, p 607 (ch 53, rescues of prisoners in custody for felony). Blackstone also cites two Acts, now repealed 'By the statute, 16 Geo II [1742], c 31 to assist a prisoner in custody for treason or felony with any arms, instruments of escape, or disguise, without
} 
In the first edition of his work in 1822, Archbold summarised the position, with specimen forms of indictment:

- Negligent Escape. If a person escaped due to the negligence of the constable, the punishment of the constable was a fine. If the negligence was that of a private person, the punishment was a fine or imprisonment, or both (the punishment was nothing, if the imprisonment of the escapee was not for a criminal matter);

- Escape from a Constable. To escape from the custody of a constable, the punishment of the escapee was a fine and imprisonment;

- Jailer-Voluntary Escape. A jailer permitting a voluntary escape was punishable to the same extent as the offence for which the prisoner was found guilty (whether treason, felony or trespass). This was determined after the prisoner was convicted (if at all). Until then, it was fine and imprisonment for a misdemeanour;

- Prison Breach. This was felony, with clergy, if the prisoner was in custody for treason or felony (following the Statute de Frangentibus Prisonam, see 5) and fine and imprisonment if for any other offence;

- Rescue. Fine and imprisonment as for a misdemeanour, if the party rescued was not convicted of the offence for which he was in custody. However, if the prisoner was convicted for HT, then HT. If for felony, then felony with clergy. If for a misdemeanour, then the same. ${ }^{107}$

However, by this time, legislation had also made some provision for matters in respect of rescue ${ }^{108}$ and in respect of escape. ${ }^{109}$

In conclusion, by the $19^{\text {th }}$ century, some complexity was removed (in terms of exceptions). However, more was added by legislation.

\section{Major Changes in Modern Times}

Prior to considering the modern legal position - as enunciated by Archbold (see 9-11) - the major changes that have occurred in this area of law since 1822 should be noted - not least to show why it is not especially advisable to rely on the former historical position. These changes are as follows:

- Private Prisons. In early times there were many private prisons-criminal and ecclesiastical. Legal writers had to take these into account—as well as the fact that the jailers would likely be of little competence and reluctant to put their own lives at risk, to prevent prisoners escaping. Thus, even in 1739, Hawkins (in the third edition of his work) referred to 'the common gaol [i.e. a royal prison], or the house of a constable [a police cell] or private person [i.e. a franchised prison], or the prison of the ordinary [a bishop's prison] '. ${ }^{110}$ Further, the 'stocks' was regarded as a form of imprisonment. ${ }^{111}$ Today, prisons are Crown prisons and the stocks no longer exist, simplifying things;

\footnotetext{
the knowledge of the gaoler; or any way to assist such prisoner to attempt an escape, though no escape be actually made, is felony, and subjects the offender to transportation for seven years. And by the statutes 25 Geo II [1751], c. 37 and 27 Geo II [1754], c. 15 to rescue, or attempt to rescue, any person committed for murder, or for any of the offences enumerated in that act, or in the Black Act 9 Geo I [1722], c 22 is felony without benefit of clergy.'

${ }^{107}$ Archbold, n 17, pp 303-310 (1822 ed). For a useful statement as to the law of escape, prison breach and rescue by 1843 , see J Gabbett, $A$ Treatise on the Criminal Law (Dublin, 1843), vol 1, ch 20.

${ }^{108}$ Thus, Archbold noted that, if the rescuers were convicted of felony, the court (at its discretion) could adjudge them to be transported for 7 years or to be imprisoned or imprisoned with hard labour for 1-3 years $(1 \& 2$ Geo 4 (1821) c. 88, s 1). Rescuing persons in custody against the Black Act was felony with death ( $25 \mathrm{Geo} 2, \mathrm{c} 37, \mathrm{~s} 9)$. Assaulting or beating a constable, to obstruct, resist or prevent the apprehension of a person for felony (besides the ordinary punishment for misdemeanours) was punishable with imprisonment with hard labour for 6 months to2 years $(1 \& 2$ Geo $4(1821)$ c 88, s 2$)$.

${ }^{109}$ Conveying files to a prisoner to enable him to escape was felony with transportation for 7 years if the prisoner was at the time convicted of treason or felony (or committed for treason or felony expressed in the warrant). It was a misdemeanour with fine and imprisonment if convicted or committed for any other offence or for a debt, damages, or costs in a civil case amounting to $£ 100(16$ Geo $2(1742)$ c 31 , s 2). Aiding and assisting a prisoner to attempt to escape from gaol— though no escape was actually made — was punishable in the same manner (Ibid, s 1). Aiding or assisting a prisoner in custody for treason or felony (petty larceny excepted) to make his escape from the constable or officer conveying him under a warrant to prison or from a person conveying him to a ship for transportation, was a felony with transportation for 7 years $(16$ Geo $2(1742)$ c 31 , s 3$)$.

${ }^{110}$ Hawkins, n 4, book 2, p 124. See also Harding, n 11, ch 1.

${ }^{111}$ Ibid. This on the basis that 'imprisonment is nothing else but a restraint of liberty.' 25 Edw III stat $2 \mathrm{c}$ ii (1351) decreed that stocks were to be built in every town. The stocks fell into disuse in the early $19^{\text {th }}$ century. See Walker, n 39 (stocks) and Du Cane, n 11, p 14 (last use after 1860). As to the pillory, this was abolished in 1837. Ibid.
} 
- Exceptions. The law in this area often had to take into account exceptions in relation to liberties (sokes, that is, places of exclusive jurisdiction), ${ }^{112}$ palatinate, duchy and Cinque Ports jurisdictions, ${ }^{113}$ benefit of clergy, ${ }^{114}$ special modes of private prosecution (such as appeals of felony and informations) ${ }^{115}$ and writs relating to prison. ${ }^{116}$ All these have now been abolished;

- Constables etc. In earlier times, constables and headboroughs ${ }^{117}$ were paid for by the village, town or borough to perform a police function. They were often part-time and a by-word for incompetence. ${ }^{118}$ Further, there were high sheriffs, under (deputy) sheriffs and bailiffs who could also arrest—as well as private persons. Today, a professional police force handles such matters, again simplifying things. ${ }^{119}$ Further, prison officers have the same status as police officers; ${ }^{120}$

- $\quad$ Treasons, Felonies, Misdemeanours. Until 1967, this categorisation prevailed and it was central to the development of the law on escape, prison breach and rescue since the law imposed more onerous penalties in the case of treasons and felonies-where the death penalty applied. Today, the death penalty has been abolished for all offences. Further, although treasons still exist, in practice, they are (effectively) obsolete. ${ }^{121}$ Thus, the (often chaotic) distinctions - and legal niceties in respect of felonies and treasons - are no longer of merit, or needed; ${ }^{122}$

- Escape and Prison Breach. A distinction between escapes and prison breach only existed in other to punish more heavily the use of force by the prisoner since it would often lead to the injury (or death) of the jailer or damage to the prison. Further, it was very important in times past-since the crime was then either a felony meriting death (i.e. where force was used) or simply a misdemeanour. Today, there is no need of such a distinction and any injury, death or damage arising during an escape etc. (i.e. any use of force) may be punished separately where it actually leads to an offence (for murder, grievous bodily harm, assault, battery, criminal damage etc.). Otherwise, it is simply de minimis;

- Imprisonment of Debtors. In the past, a large volume of the prison population comprised persons who had committed no criminal offence - but a civil one. The law sought not to impose such a harsh punishment in their case of escape etc. Today, persons imprisoned for civil matters are much rarer (the Debtors Act 1869 started the process of reducing the grounds for imprisonment) and the likelihood of

\footnotetext{
${ }^{112}$ The Crown practice of creating sokes ended by the time of Edward III (1327-77). However, many were created (especially ecclesiastical ones in London, such as those of the Bishop of London and St Paul's. These lasted for centuries). See GS McBain, Liberties and Customs of the City of London-Are there any Left? International Law Research (2013), vol 2, no 1, p 37. Also, Hawkins, n 4, book 2, p 130 (privilege of franchise).

${ }^{113}$ For the palatinates, see GS McBain, Abolishing some more Obsolete Crown Prerogatives (2011) Liverpool LR, vol 32, no 1, p 83-6. The only palatinates which exist today comprise those of: Chester, Durham and Lancaster. However, they no longer have a distinct criminal or civil jurisdiction (including any rights of arrest or private prisons). Nor do the Cinque Ports or the duchies of Lancaster or Cornwall. For these, see GS McBain, The Charters of the Cinque Ports - Are they Still Needed? (2013) Review of European Studies, vol 5, no 2, pp 90-126, GS McBain, Time to Abolish the Duchy of Lancaster (2013) Review of European Studies, vol 5, no 4, pp 172-93 and GS McBain, Time to Abolish the Duchy of Cornwall? (2013) Review of European Studies, vol 5, no 5, pp 40-58.

${ }_{114}$ The principle of benefit of clergy was abolished in 1827. See Walker, n 39 (benefit of clergy) and Hawkins, n 4, book 2, p 130 (benefit of clergy).

${ }^{115}$ Walker, $\mathrm{n} 39$ (appeal of felony) 'In the case of death by murder or manslaughter the feudal lord of the deceased, the widow, or the heir male might bring an appeal, in substance an accusation or challenge or claim for loss to himself rather than for harm to the public'. Appeal of felony was abolished in 1824. Until 1938 an information could be filed by the sovereign's coroner (commonly called the Master of the Crown Office) acting on the orders of the King's Bench division, at the request of a private individual. Until 1967, an information could be filed ex officio by the Attorney-General (or Solicitor General) at his own instance. See GS McBain, Abolishing Criminal Libel (2010) Australian LJ, p 440.

${ }^{116}$ For example, Walker, n 39 (mittimus) 'a written command to the keeper of a prison to receive and keep safe, until released in due course of law, a person charged with any crime.' Thus, if a person was committed to prison on a mittimus, it was held that he was in lawful custody (eg. Hawkins, $\mathrm{n}$ 4, book 2, p 124). So too, when imprisoned on a capias ad satisfaciendum (Ibid). These writs no longer exist. Further, people are no longer committed to prison on 'reasonable cause of suspicion' (Ibid) which led Hawkins to puzzle as to whether this could constitute lawful custody.

${ }_{117}^{11}$ See $\mathrm{n} 39$.

${ }^{118}$ JF Stephen, History of the Criminal Law of England (Macmillan, 1883), vol 1, p 196 'Nothing could exceed the inefficiency of the constables and watchmen. Of the constables, Dalton (in the reign of James I) [this is a reference to M Dalton, The Countrey Justice. London. For the Society of Stationers. 1619] observes that they 'are often absent from their houses, being for the most part husbandmen, and so most of the day in the fields.' The charge of Dogberry shows probably with no great caricature what sort of watchmen Shakespeare was familiar with.'

${ }^{119}$ High sheriffs still exist, but have only a ceremonial role. Private persons can arrest. However, this is rare in practice (judges and justices of the peace have no greater powers than an ordinary citizen in this respect). The last local police force (in Hove) ended in 1898.

${ }^{120}$ Prison Act 1952, s 8.

${ }^{121}$ See McBain, $\mathrm{n} 3$.

${ }^{122}$ For example, what if a prisoner escapes and then his offence becomes capital (eg. he wounds a man who dies after his escape)? See Hawkins, $\mathrm{n} 4$, book 2, p 126. What if the crime for which a person is imprisoned is later held not to be capital (eg. killing in self defence)? Ibid. What if a person escapes and rescues at the same time other prisoners there guilty of HT although he did not know what they were in for- did he commit HT ? Ibid, p 140. See also 12.
} 
escape, prison breach and rescue is even less (not least, because sentences are usually short). This should be noted;

- $\quad \underline{\text { Fines. }}$. In early times, amercement ${ }^{123}$ was routinely applied in the case where persons had failed to do their job (that is, perform their office) properly. Thus, in the case of an escapee, sometimes, the jailer would be amerced and/or the person who held the franchise ${ }^{124}$ or who was otherwise responsible for the prison (such as the sheriff). ${ }^{125}$ The cases and legal commentators often refer to negligent jailers being fined - which would seem to be correct where they were paying a fine in lieu of their being imprisoned for their default. ${ }^{126}$ As Bellamy and Pollock and Maitland point out, it was not a case of imprisonment and a fine, the fine was paid to avoid imprisonment or to reduce the time a person was condemned to spend there. ${ }^{127}$ Thus, fines were an important part of revenue raising for the sovereign-especially when there were few prisons. Today, the position is quite different and fines as a revenue raising alternative to imprisonment should be irrelevant in this context. It is asserted, therefore, that fines, should be abolished in the context of escape, rescue and prison breach-all of which should merit a prison sentence (not least, to deter rescuers and officers who permit voluntary escapes). ${ }^{128}$

Another major change was confirmed in $R v$ Frascati $(1981)^{129}$ where the court held that-whatever may have been the position in the past - escape was an offence in itself. ${ }^{130}$ It did not depend on the outcome of the trial in respect of which the escapee was in custody. In this case the escapee escaped from a police cell at the magistrate's court and was subsequently found not guilty of the charge on which he was placed in the cell. ${ }^{131}$ This case effected a major change in that -in the past - prison breach, rescue and permitting escape (ie. voluntary escape) were linked to the issue of whether the escapee was guilty of felony or not. ${ }^{132}$ The decision in Frascati to recognise that there is no link and that escape, per se, is a crime - is indubitably a better, and more modern, approach.

For all these reasons, for the modern law on escape, prison, breach, rescue and permitting escape to refer back to old authorities and cases is unwise and, today, a modern re-statement of the law which is more coherent and clear is required.

\footnotetext{
${ }^{123}$ Walker, $\mathrm{n} 39$ (amercement) 'In English law a pecuniary penalty for an offence, where the ofender was brought before the court of his lord, whether king or subject superior, and was at the mercy of the lord, The amount seems originally to have been arbitrary but later came to be settled by custom...' See also Pollock \& Maitland, n 29, vol 2, pp 513-5.

${ }^{124}$ See for example, n 79 where Simon Seagrave (custodian of the Tower of London) was severely amerced by Edward II for letting Roger Mortimer escape from the Tower of London.

${ }^{125}$ This could be draconian. For example, in 1395, a creditor brought a bill of complaint against William Shiryngham and Robert Elys, sheriffs, for an unpaid debt of c. $£ 182$ owed by a prisoner in Newgate prison. The creditor asserted the sheriffs were liable in allowing the prisoner to escape. In turn, the sheriffs argued they had appointed a deputy to guard the jail. Thus, he was responsible. Their defence was rejected and the sheriffs were committed to prison until they paid the debt. See AH Thomas, Calendar of Select Pleas and Memoranda of the City of London 1381-1412 (Cambridge UP, 1932), p 233. This partly explains why people often did not want to be sheriffs, constables etc. As a result, it is a common law crime to refuse to take up a public office.

${ }^{126}$ See Hawkins, n 4, book 2, p 136 'where-ever a person is found guilty upon an indictment, or presentment, of a negligent escape of a criminal actually in his custody, he ought to be condemned in a certain sum to be paid to the king, which seems most properly to be called a fine; but this doth not appear clearly from the old books, for in some of them it seems to be taken as a fine, in others as an amercement, and in others it is spoken of generally, as an imposition of a certain sum, and without any mention either of fine or amercement.'

${ }^{127}$ Bellamy, n 11, p 190 'The fine was really the result of a bargain for release struck between the king and the offender. The sentence was not 'pay a fine or suffer imprisonment' but 'go to prison and then if you can offer the king sufficient financial inducement you may obtain reléase.' See generally, ch 6. This was also pointed out by Pollock \& Maitland, n 29, p 517 'What the judges can do is this:- they can pronounce a sentence of imprisonment and then allow the culprit to 'make fine', that is to make an end (finem facere) of the matter by paying or finding security for a certain sum of money. In theory the fine is a bilateral transaction, a bargain; it is not 'imposed', it is made.'

${ }^{128}$ Today, the modern 'fine' is not the same as the older concept of 'fine' which was paid as an alternative to imprisonment. Today, fines are paid 'and/or' with imprisonment, in the case of escape, rescue and prison breach. See generally, JC Fox, The History of Contempt of Court (rep Professional Books Ltd, 1972), p 200. Nor is the modern fine an amercement.

${ }_{129} 73$ Cr App R 28.

${ }^{130}$ The court referred to 'prison breach without the use of force' and to 'escape from lawful custody.' However, it mean't escape. See p 30.

${ }^{131}$ The escapee was on remand in custody, awaiting trial on a charge of conspiracy to defraud and other allied offences. He escaped from a police cell through a sky-light window (it appears there was no force; therefore, it was escape - not prison breach). He was later re-captured. The court held the fact that he was not found guilty of the charge in respect of which he was imprisoned was not relevant. Kenneth Jones $\mathrm{J}$ 'today, since the death penalty and the distinction between felony and misdemeanour have both gone, it would seem that there is no authority whatsoever for holding that acquittal of the principal offence is an answer to the present day offence of breach of prison. But what is abundantly clear is that there never was authority, either in Hale or in Hawkins, for the proposition that such an acquittal was an answer to the charge of the misdemeanour or prison breach without the use of force. That misdemeanour has been replaced, as I have pointed out, by the offence today of escape from lawful custody.'

${ }^{132}$ Thus, although the court did not say it directly, prison breach, permitting escape and rescue are also all now crimes in themselves—and not linked to any underlying offence in the person who flees from lawful custody. This is important because it means there is no need now to have distinct crimes of escape and prison breach. The issue of force should now go to the sentence, not to the crime.
} 


\section{Modern Law of Escape}

As to the modern law of escape, prison break and rescue, this is dealt with in short form in Archbold (2013 ed). In respect of escape, it provides that:

It is an indictable offence at common law, punishable by fine and imprisonment, for a prisoner to escape without the use of force from lawful custody on a criminal charge or by civil process. ${ }^{133}$

As authority for this, Archbold refers to Hawkins ${ }^{134}$ and Hale. ${ }^{135}$ Archbold also notes the following:

\section{(i) Nature of Legal Custody}

As to the concept of legal custody, in $R v$ Dhillion (2006), ${ }^{136}$ the court held that the prosecution must prove that: (a) the defendant was in custody; (b) the defendant knew he was in custody (or, at least, was reckless as to whether he was or not); (c) the custody was lawful; and (d) the defendant intentionally escaped from lawful custody. As to this, a person in custody on a lawful charge includes a person in:

- lawful custody following arrest; ${ }^{137}$ or

- custody awaiting trial, sentence or serving a sentence, ${ }^{138}$ or

- transit to (or from or at) a prison, remand centre, court etc. ${ }^{139}$

Whether a person can be said to be in legal custody at any time was a question of fact. Regard may be also may be had to the Prison Act 1952 (legal custody of a prisoner):

- Section 13(1) provides that every prisoner shall be deemed to be in the legal custody of the governor of the prison;

- Section 13 (2) provides that a prisoner shall be deemed to be in legal custody while he is confined in (or is being taken to or from) any prison and while he is working, or is for any other reason, outside the prison in the custody or under the control of an officer of the prison and while he is being taken to any place to which he is required or authorised by or under this Act or certain other Acts ${ }^{140}$ to be taken, or is kept in custody in pursuance of any such requirement or authorisation.

Archbold also notes that:

- 'custody' is to be given its ordinary and natural meaning viz. a person's immediate freedom of movement being under the direct control of another. ${ }^{141}$ A person on bail was not in lawful custody. Therefore, if he absconded, he did not commit the offence of escape. ${ }^{142}$ A prisoner on temporary release from prison who failed to return to the same at the expiry of the release period, could not be said to have escaped from custody. Therefore, he could not be guilty of escape; ${ }^{143}$

- 'escape' occurs where a person having a prisoner lawfully in his custody, voluntarily or negligently suffers him to go at large. A custodian is guilty of an offence if he 'voluntarily' or 'negligently' allows his prisoner to escape from lawful custody. ${ }^{144}$ Archbold relies on old authorities that there is no escape if the prisoner is not lost sight of between the attempted escape and re-capture. ${ }^{145}$

\footnotetext{
${ }^{133}$ See para 28-166. Also, $R$ v Allen (1841) Car \& M 295 (174 ER 513). Indicted for aiding a prisoner escape from Ilchester jail. The court held it was a misdemeanour, indictable at common law, to aid a person to escape from custody even if he was confined in respect of a civil offence (he was confined under the remand of the Commissioners for the Relief of Insolvent Debtors).

${ }^{134}$ Hawkins, n 4, book 2, c 19 (of escapes suffered by officers). Punishment for escape is fine and (or) imprisonment. See Archbold, n 17, para 28-172. Cf. Blackstone CP, n 19, B14.69. It is a common law offence punishable on indictment by a fine and imprisonment at large, to escape from legal custody.

${ }^{135}$ Hale, n 4, vo1, p 590 (of felony by voluntary escapes).

${ }^{136}$ (2006) 1 Cr App R 15. See also Blackstone CP, n 19, B14.69 and Waters (1873) Cox CC 390 (irrelevant whether he was guilty of crime for which he was arrested or imprisoned).

${ }^{137} R$ v Timmis [1976] Crim LR 129.

${ }^{138} R v$ Hinds (1957) 41 Cr App R 143 (walked out of a prison door).

${ }^{139} R v$ Moss and Harte (1985) 82 Crim App R 116 (escaped from a magistrates' court).

${ }^{140}$ Prison Act 1952, ss 95, 98, 99 or 108(5). See also Powers of the Criminal Courts (Sentencing) Act 2000 and the Criminal Justice and Court Services Act 2000. See generally, Archbold, n 17, para 28-170 and Blackstone CP, n 19, B 14.70.

${ }^{141}$ See cases cited by Archbold, n 17, para 28-166.

${ }^{142} \mathrm{Ibid}$. Cf. Where a defendant surrendered to the custody of a court, he was in the control of the court, regardless of whether he was subjected to physical restraint or had anyone physically present to restrain and control him. See also Rv Rumble [2003] 167 JP 205.

${ }^{143}$ He might, however, be guilty under the Prisoners (Return to Custody) Act 1995, s 1 (see (ii) in text). See Archbold, n 17, para 28-166. Also, Montgomery [2008] 1 WLR 636 and Blackstone CP, n 19, B14.70.

${ }^{144}$ Archbold, n 17, para 28-166.

${ }^{145}$ It cites Hale, $\mathrm{n} 4$, vol 1, p 602, Hawkins, $\mathrm{n} 4$, vol 2, c 19, ss 6 \& 13. Also, $R v$ Keane [1921] NZLR 581. Archbold notes 'If the prisoner has not escaped, a conviction for attempt would be a possible alternative verdict in appropriate circumstances.' It cites the Criminal Law Act 1967, s 6(4).'
} 
Archbold also notes that persons who aid a prisoner to escape are — at common law_-guilty as principal, or may be indicted for rescue. ${ }^{146}$ And that the Prison Act 1952, s 8 provides that every prison officer while acting as such shall have the powers, authority, protection and privileges of a constable. ${ }^{147}$

\section{(ii) Relevant Legislation}

Archbold also cites legislation which deals with escape and assisting escape:

- Assisting Escape. The Prison Act 1952, s 39 provides it is a crime for a person who: (a) assists a prisoner in escaping (or attempting to escape) from a prison; or (b) who, intending to facilitate the escape of a prisoner, (i) brings, throws or otherwise conveys any thing into a prison; (ii) causes another person to bring, throw or otherwise convey any thing into a prison, or (iii) gives any thing to a prisoner or leaves any thing in any place (whether inside, or outside, a prison); ${ }^{148}$

- Harbouring Escaped Person. The Criminal Justice Act 1961, s 22 provides that it is a crime if a person knowingly harbours: (a) a person who has escaped from a prison or other institution to which $\mathrm{s}$ 39 applies; (b) one who, having been sentenced in any part of the UK (or in any of the Channel Islands or the Isle of Man) to imprisonment or detention, is otherwise unlawfully at large. Also, one who gives to any such person any assistance with intent to prevent, hinder or interfere with his being taken into custody; ${ }^{149}$

- At Large after Temporary Release. The Prisoners (Return to Custody) Act 1995, s 1 provides that it is an offence if a person temporarily released in pursuance of rules made under s 47(5) of the Prison Act 1952: (a) without reasonable excuse, remains unlawfully at large at any time after becoming so at large by virtue of the expiry of the period for which he was temporarily released; or (b) knowing (or believing) an order recalling him to have been made and while unlawfully at large by virtue of such an order, fails, without reasonable excuse, to take all necessary steps for complying as soon as reasonably practicable with that order; ${ }^{150}$

- Hospital Patients. It is an offence to induce (or knowingly assist) a person liable to be detained in hospital or who is subject to guardianship under the Mental Health Act 1983 or who is a community patient, to absent himself. ${ }^{151}$ It is also an offence to induce (or knowingly assist) a person in legal custody under the Mental Health Act 1983 to escape, or to harbour or assist a person unlawfully at large to remain at large. ${ }^{152}$

\section{In conclusion, legislation has intruded into the area of escape.}

\section{Archbold-Prison Breach}

Archbold states that:

It is an indictable offence at common law, punishable by fine and imprisonment, to breach prison. Breach of prison consists in the escape from lawful custody by the use of any force. ${ }^{153}$ It is immaterial

\footnotetext{
${ }^{146}$ Archbold, n 17, para 28-166.

${ }^{147}$ Ibid. Archbold also deals with the powers and duties of prison custody officers employed at contracted out prisons.

${ }^{148}$ It says a 'felony'. See also Russell, $\mathrm{n} 4$, vol 1, p 337. Also $R$ v Payne (1866) LR 1 CCR 27. See also Archbold, n 17, para 28-168. A person is guilty of assisting a prisoner to escape from prison even if the escape occurred while the prisoner was doing work outside the prison. $R$ v Abbott [1956] Crim LR 337. See also Blackstone CP, n 19, B 14.73; Nicoll v Catron (1985) 81 Cr App R 399 (police station yard not a 'prison or other institution' under s 39) and Archbold Procedure, n 19, para 20-142.

${ }_{149}$ Archbold, n 17, para 28-170. See also Blackstone CP, n 19, B14.73; Archbold Practice, n 19, para 20-142 and Darch v Weight (1984) 79 Cr App R 40 (merely giving assistance to an escaped prisoner does not mean harbouring).

${ }^{150}$ See also Blackstone CP, n 19, B14.72. This offence does not apply to persons temporarily released from secure training centres, $\mathrm{s} 1(2)$. See also Archbold Practice, n 19, para 20-143B and Montgomery (2008) 1 WLR 636 (failing to return to an open prison after permitted day release is not escaping from lawful custody). Cf. Golding (2007) 2 Cr App R (S) 49.

${ }^{151}$ See generally, Archbold, n 17, para 28-171.

${ }^{152}$ Ibid.

${ }^{153}$ Archbold, n 17, para 28-183 'It must be proved that the prisoner was in prison as alleged; and that, while in custody there, he broke prison and escaped. The breaking proved must be actual breaking; merely getting over the walls, or passing out through a door, or the like, is an escape only, and not a breach of prison. Archbold cites Hale, n 4, vol 1, p 611 who stated 'If the gaoler set open the prison doors and the felon escape, this may be a felony in the gaoler, but is no breach of prison to make felony in the prisoner'. (Hale himself cites Coke, $\mathrm{n} 13$, vol 2, p 589 which contains a fuller statement). Archbold also cites $R v$ Burridge (1735) 3 P Wms 439 (24 ER 1133) in which Hardwicke CJ, p 1149 , stated 'I believe no man ever saw, either in authority, practice, or precedent, an indictment for a rescue without the word rescussit; and certainly, that must be charged, or something equivalent to it, to how that it was forcible, and against the will of the officer who had the prisoner in his custody.' Archbold continues 'But the breaking need not be intentional; and therefore where a prisoner, in effecting his escape, by accident threw down some loose bricks at the top of the prison wall placed there to impede escape and give alarm, it was held to be prison breach. $R v$ Haswell (1821) R \& R 458.'
} 
whether the custody is criminal or civil and whether the prisoner is actually within a gaol or is only in the constable's house or lock-up, provided that he is lawfully imprisoned and restrained of his liberty. ${ }^{154}$

While this statement is correct, it is not above criticism: (a) Archbold does not deal with the position on treason which can apply to prison breach as well as to escape and rescue; (b) Archbold cites Russell (writing in 1964) who merely cites Hawkins (1824 ed). ${ }^{155}$ As a result, the formulation is archaic (also, people tend to refer to 'police stations' these days as opposed to a 'constable's house or lock-up'); (c) the fine and imprisonment imposed in times past tended to be different where the breach was of prison, a constable's or a private person's custody, these crimes being graduated, in terms of severity. This is not noted.

It is asserted this distinct crime of 'prison breach' should be abolished for the following reasons:

- As previously noted, the distinction between escape and prison breach - the latter requiring some degree of force - stretches back to 1295 and, indeed, before. The need for 'force' was linked to it being a felony in every case to escape from prison, using force, prior to 1295 and a felony thereafter, if the person was committed for felony;

- However, with the death penalty no longer applying for any crime (since 1998) and with the categorisation of crimes into treason, felony and misdemeanour having gone (since 1967), there is no need to preserve this crime as such. 'Escape' should cover escape both with, or without, force (the distinction now not being material to the offence);

- The degree of 'force' in times past could be minimal and such a distinction is of little merit today ${ }^{156}$ Further, the punishment for escape and prison breach is now the same: fine and imprisonment. In Coughtrey (1997), ${ }^{157}$ McCowen LJ noted that prison breach was a very serious offence for which a substantial sentence of imprisonment was to be expected due to the: (a) fear and apprehension it generated; (b) disruption to prison life; (c) violence and disorder it might lead to; (d) need to deter the culprit and others. However, these issues also apply to escape. Thus, any force used (if at all) in an escape should be reflected in the sentence-not in separate crimes.

In conclusion, it is asserted that the common law crime of 'prison breach' should be abolished and that a legislative crime of escape should cover situations both where force is-and is not-used (i.e. force being immaterial to the crime, but not to the sentence).

\section{Archbold-Rescue}

Archbold states that:

Rescue at common law is forcibly liberating a prisoner from lawful custody. ${ }^{158}$ If the prisoner is in private custody, the rescuer is not criminally liable unless he knew that the person was in custody on a criminal charge...

Fine and (or) imprisonment [if the person rescued has not been convicted of the offence for which he was in custody]. ${ }^{159}$

\footnotetext{
${ }^{154}$ Archbold, n 17, para 28-182. Archbold also notes 'The subsequent dismissal of the charge on which the prisoner was imprisoned is no defence to an indictment for breach of prison by the prisoner while in custody on that charge.' Archbold cites $R v$ Frascati (see 8). See also Blackstone CP, n 19, B14.71.

${ }^{155}$ Russell, $\mathrm{n} 4$, vol 1, p 334 'Where the prison breaking is by a party lawfully confined upon a charge of misdemeanour, it is punishable as a misdemeanour, by fine and (or) imprisonment.' Russell then refers to Hawkins, $\mathrm{n} 4, \mathrm{c} 18$, s 21 and to $R v$ Allen (see $\mathrm{n}$ 133).

${ }^{156}$ If the prison door was open, it was escape. However, if any degree of force was needed, it was prison breach. Today, given the solid construction of prisons (and their doors) most prisoners would rather use subterfuge or easier methods to quit prisons, rather than force. Blackstone CP, n 19, para B14-71 states 'The offence is similar to escape, but must involve some breaking, cutting, or forcing in the course of the escape. It need not involve escape from an actual prison (forcing open a police station window would suffice) and need not involve any deliberate damage'.

${ }^{157}$ [1997] 2 Cr App R (S) 269. An offender serving a life sentence for murder escaped after 2 years by burning through the perimeter fence with cutting equipment and then scaling the outer wall. He was sentenced to 7 years, reduced to 4 on appeal. See also Blackstone CP, n 19, para B.14.71.

${ }^{158}$ Archbold, n 17, para 28-185 cites Coke, n 4, vol 1, 160 (Coke stated, vol 1, 160b 'Rescous. Rescussus...is an ancient French word coming from rescourrer (id est) recuperare, that is, to take from, to rescue or recover...' The rest of what Coke stated is not material, relating to distress). Archbold also cites Hale, n 4, vol 1, p 606 who stated 'Rescue of a person imprisoned for felony is also felony by the common law'. Archbold also cites Hawkins, n 4, book 2, c 21 who stated 'The offence of a stranger in forcibly freeing another from an arrest, comes under the notion of rescous, which in most instances is of the same nature with the offence of breaking prison.' Finally, Archbold also cites Russell, $\mathrm{n} 4$, vol 1, p 335 who stated 'Rescue, or the offence of forcibly and knowingly freeing another from arrest or imprisonment is, in most instances, of the same nature as prison breaking.'

${ }^{159}$ Reference is made to Hawkins, $\mathrm{n} 4$, book 2 , c $21 \mathrm{~s} 8$ (the rescuer can only be arraigned after outcome of the sentence re the prisoner. However, it is a misprison in the meantime). Archbold contines 'It must be proved that the [prisoner] was in the lawful custody of a police constable. If the party was convicted, the conviction must be proved by a certificate of the proper officer. PACE Act 1984, s 73. Further, that
} 
It is asserted the wording of Archbold in brackets above should no longer be followed after $R v$ Frascati (1981). ${ }^{160}$ That is, the punishment for rescue should not be linked to whether the person freed is subsequently guilty — or not guilty — of a crime. Instead, rescue (like escape and prison breach) should be a crime in itself.

Thus, this 'link' between the punishment and the underlying crime for which the prisoner was in for, should be broken. As previously noted, this link related to the death penalty and to the categorisation of crimes into treasons, felonies and misdemeanours. It is not appropriate after 1967 when that categorisation became redundant and especially so after 1998 when the death penalty for all offences was abolished.

Further, it is asserted - in any case - this common law crime of 'rescue' should be abolished. Instead, the crime should be a legislative one; that of 'assisting' a person to escape, being linked with the Prison Act 1952, s 39 (see 9(ii)). This should apply regardless of whether force is used or not (as with escape). After all, waiting with a car to drive away an escaped prisoner is just as culpable as forcibly opening a prison door, to enable a prisoner to escape.

In conclusion, it is asserted that the common law crime of 'rescue' should be abolished. A legislative crime of 'assisting an escape' should cover situations where force is-or is not-used (i.e. force being immaterial to the crime, but not to the sentence).

\section{What of High Treason?}

Archbold states (as to rescue $r$ HT, without noting that it would also apply to escape and prison breach): ${ }^{161}$

The offence is generally treason or misdemeanour according to the quality of the person rescued; but if the latter is not convicted of the offence for which he was in custody, the rescue is only a misdemeanour...If he has been convicted for high treason, the rescue is high treason: if for a misdemeanour, the rescue is for a misdemeanour. ${ }^{162}$

Halsbury states:

a person who rescues a prisoner he knows to be guilty of treason is himself guilty of treason and liable to the punishment for that offence. ${ }^{163}$

Finally, Russell (writing in 1964) states that:

A stranger who rescues a person committed for and guilty of high treason, knowing him to be so committed, is guilty of high treason, whether he knew that the party rescued was guilty of high treason or not, and he would, in like manner, be guilty of felony by rescuing a felon, although he knew not that the party was imprisoned by felony. ${ }^{164}$ (underlining supplied)

First, it is asserted that these statements of Archbold and Halsbury are incorrect today. Second, it is asserted that Russell's statement - that a person is guilty of HT if he rescues from prison a person committed for HT even if the rescuer does not know this, is incorrect today.

\section{(a) Archbold \& Halsbury Incorrect}

I believe Archbold and Halsbury are incorrect on this matter for the following reasons:

- 1423 Act now Repealed. The 1423 Act — which provided that the escape of a person committed for HT was HT - was repealed in 1863 . Therefore, a person committed for HT today who escapes, does not, thereby, commit HT. Since prison breach is an exacerbated form of escape, the level of punishment may increase, but not the nature of the offence. Thus, a person committed for HT who commits prison breach today does not also commit HT. And since prison breach and rescue merit the same punishment, nor does a person who rescues one committed for HT;

- Treason Act 1351 Declaratory of Treason. Even if the above is incorrect, the peculiar nature of the Treason Act 1351 (the '1351 Act') must be taken into account. It declared the law on HT, superceding

whilst so in custody he forcibly rescued him. As to evidence for the defence, it may be observed that any circumstance that will excuse a breach of prison will excuse a rescue.' Archbold cites Hawkins, n 4, book 2, 21 ss $1 \& 2$ (necessity etc).

${ }^{160}$ See n 129.

${ }^{161}$ Archbold, n 17, paras 185-6. This suggests that Archbold referred to Halsbury, n 18, vol 11(2), pp 137-8 since Halsbury also fails to do this.

${ }_{162}$ Ibid, para 28-185 cites Hale, n 4, vol 1, p 607 'As in the case of an escape, so in the case of a rescue...' See also Archbold, n 17, para 28166 'a custodian who 'voluntarily' suffers the escape of a man in custody for treason, is guilty of treason.'

${ }^{163}$ Halsbury, n 18, vol 11 (2) at p 138. However, this statement of Halsbury is not of much use since it refers to Bensted's Case (1640) without noting that that case wholly depends on Exeter's Case (1421).

${ }^{164}$ Russell, n 4, vol 1, p 335. 
the common law, ${ }^{165}$ such that HT could only then be made by way of legislation and not the common law. The Treason Act 1351 declaratory clause made this clear. Thus, after the 1351 Act, HT could only be created by legislation. The subsequent history of the law of treason indicates that this has been adhered to. ${ }^{166}$ Today, only the Treason Acts 1351 and 1702 state what are HT. ${ }^{167}$ Thus, no common law treasons exist or can exist - the Treason Act 1351 precludes this; ${ }^{168}$

- 1295 Act (Statutum de Frangentibus). All treasons are felonies (although not all felonies are treasons). Thus, prior to the 1423 Act (see 6), it is likely that a person who was committed for HT who escaped would have been executed as a felon. Further, prior to that Act, such a person committed felony anyway. By 1423, however, the Treason Act 1351 was in existence and, therefore, there was (obviously) regard as to whether escaping in the case of HT should bear a more severe punishment than felony. The 1423 Act made it so - and this then affected rescue and prison breach. However, both the 1295 and 1423 Acts have now been repealed, leaving the Treason Act 1351 to govern the issue.

In conclusion, I believe the error made by Archbold and Halsbury is to quote older authors without realising that they were referring to a situation when the 1295 and 1423 Acts were extant. ${ }^{169}$ However, these Acts have now been repealed. Moreover, since 1967, it is not a felony (i.e. merits the death penalty) to escape or commit prison breach or rescue. Therefore, after 1967, it would be an anomaly if this was so in the case of treason-since all treasons are felonies. ${ }^{170}$ Further, the 1351 Act abolished all common law treasons. Thus, any additional treason to escape etc. can only exist by virtue of statute and there is no Act currently providing for it.

\section{(b) Russell is Incorrect}

Russell (writing in 1964) stated that a stranger who rescues a person committed for-and guilty of HT - is guilty of HT whether he knew that the party rescued was guilty of HT or not. For this proposition Russell relied on Hale and on Bensted's Case (1640). ${ }^{171}$ Hale (writing in the 1640's) stated:

To make a rescue felony the party rescued must be under custody for felony or suspicion of felony, and it is all one, whether he be in custody for that account by a private person, or by an officer or warrant of a justice, for where the arrest of a felon is lawful, the rescue of him is a felony. It seems that it is necessary, that he should have knowledge that the person is under arrest for felony, if he be in the custody of a private person.

But if he be in the custody of an officer as constable or sheriff, there at his peril he is to take notice of it, and so it is if there be felons in a prison, and A not knowing of it breaks the prison and lets out the prisoners, tho he knew not that there were felons there, it is felony; and if traitors were there, it is treason. P 16 Car 1. Croke, $p$ 583. Bensted's case per omnes justiciarios [by all the judges]. ${ }^{172}$ (italics supplied).

Thus, Hale relied on Bensted's Case (1640) for his proposition. ${ }^{173}$ Bensted's Case (1640) was also referred to by counsel in R v Burridge (1735) ${ }^{174}$ but not by Hardwicke CJ who delivered the judgment of the court. ${ }^{175}$ Counsel

\footnotetext{
${ }^{165}$ The Law Commission considered that the common law of treason was 'entirely superceded' by the Treason Act 1351. Law Commission, Codification of the Criminal Law: Treason, Sedition and Allied Offences. Working Paper no 72 (1977), p 3. See also CS Kenny, Outlines of Criminal Law (Cambridge, 19th ed, 1966), p 396. One would agree. See generally, McBain, n 3.

${ }^{166}$ Such non-statutory treasons which arose subsequent to the Treason Act 1351 arose by way of constructive interpretation of this Act (and there were many). However, the judges were careful to indicate that they were constructively interpreting the 1351 Act, not that they were creating new common law treasons. See McBain, n 3. Further, Bensted's Case (1640) Cro Car 583 (79 ER 1101) was a constructive interpretation of the 1351 Act (ie. an interpretation holdign that some types of riot could comprise 'levying war'). In 1841, a Royal Commission on Criminal Law expressly deprecated constructive treasons and they would not be adopted today, see McBain, n 3, p 116, $n$ 227.

${ }^{167}$ The Treason Acts 1495, 1695, 1814 relate to procedure or penalty only.

${ }^{168}$ Misprision of treason is not a treason as such. It is a misprision.

${ }^{169}$ Generally, Archbold follows Halsbury vis-à-vis escape, prison breach and rescue. Here, it seems to have done so uncritically.

${ }^{170}$ See $\mathrm{n} 2$.

${ }^{171}$ Russell, n 4, vol 1, p 335 'Bensted's Case (1640) Cro Car 583, 79 ER 1101, where it is said that it was so resolved by 10 of the judges. And see 1 Hale 606. But Hawkins c 21 s 7 say that this opinion is not proved by the authority of the case (YB 1 Hen 6, 5) on which it seems to be grounded. Bensted's case is spoken of in $R v$ Burridge (1735) $3 \mathrm{P} \mathrm{Wms} 439$ as having been cited and allowed to be law at an assembly of all the judges of England, except the Chief Justice of the Common Pleas, in Limmerick's Case (1668) Kel (j) 77.' For this case, see 84 ER 1087, at 1090 .

${ }^{172}$ Hale, $\mathrm{n} 4$, vol 2, p 606. Also, vol 1, p 141 'at the same time by ten of the judges it was agreed, that the breaking of prison, where traitors were in durance, and causing them to escape was treason, altho the parties did not know that there were any traitors there, upon the case of [Exeter's case] and so to break a prison where felons are, whereby they escape, is felony without knowing them to be imprisoned for such offence.'

${ }^{173}$ Bensted's Case (1640) Cro Car 583 (see also W Jones 455 (872 ER 239)) was a constructive treason under the 1351 Act. See McBain, n 3 , p 102-7 concerning the problems relating constructive treason, as well as this case. See also 6 ST 906 and Hale, n 4 ,vol 1, p 141 (summarising Bensted's Case) 'going in a warlike manner with drums and arms to surprise the archbishop of Canterbury, who was a privy
} 
stated that Bensted's Case (1640) had been cited and allowed to be the law at an assembly of all the judges of England except the Chief Justice of the Commons Pleas (that office being vacant at the time) in Limmerick's Case (1668). ${ }^{176}$ However, this latter case adds little since Bensted's Case (1640) itself relied on Exeter's Case (1421) (see 6). For his part, Hawkins asserted (Russell also quoted him) ${ }^{177}$ that Exeter's Case did not hold that a person could be guilty of HT where he did not know the person rescued was committed for the same. Thus, Hawkins stated:

Whereas a person committed for high treason, who breaks prison and escapes, is guilty of felony only, unless he lets others also escape whom he knows to be committed for high treason, in which case he is guilty of high treason, not in respect of his own breaking of the prison, but of the rescous of the others: A stranger who rescues a person committed for and guilty of high treason, knowing him to be so committed, is in all cases guilty of high treason; and by some he is in like manner guilty, whether he knew that the prisoner were committed for high treason or not; but this opinion is not proved by the authority of the case on which it seems to be grounded. ${ }^{178}$ (italics supplied)

Thus, it all boils down to Exeter's Case. Did it really cover a lack of knowledge as to a person being a traitoras well as knowledge? Dyer (a judge of great ability) in his reports in 1555 was clear that, in Exeter's Case (1421), Exeter as the rescuer, knew the prisoners he was releasing were there for treason. Thus, Dyer stated, referring to the case:

someone who was outlawed for felony and imprisoned in the king's bench broke the prison, knowing [sciens] the prisoners to be there for treason, and brought them out, and this was adjudged treason. ${ }^{179}$

In conclusion, one would assert that Hawkins (and Dyer) are correct and that Russell (and Bensted's Case (1640)) are wrong. Thus, I believe that Exeter's Case only dealt with knowledge. If it had not, it would have created a new common law crime of treason and it asserted the 1351 Act precluded - and still precludes - this.

\section{(c) Storm in a Teacup?}

It should be pointed out that this issue is highly unlikely to occur in the future since the law of HT is obsolete in many aspects and it is very doubtful a case will arise in relation to it in the future. Indeed, it may be noted that three of the crimes which still comprise HT have never had a precedent. ${ }^{180}$ Treason in respect of 'levying war' under the 1351 Act is also most unlikely to occur. ${ }^{181}$

In conclusion, to rescue a person committed (and later convicted) for HT is not HT in the rescuer (whether he knew the person rescued was in for HT, or not). The same applies in respect of any escape, prison breach, voluntary or negligent escape.

\section{Injustice of the Law}

It is difficult not to argue that the law on escape, prison breach and rescue has created much injustice and that the life of a man (literally) often hung on a lot of specious legal analysis. Some examples might be given:

counsellor, it being with drums and a multitude (as the indictment was) to the number of three hundred persons, was ruled treason by all the judges of England, and the offenders had judgment accordingly.' It may be noted that Bensted was acquitted.

${ }^{174} R v$ Burridge (1735) 3 P Wms 439 (24 ER 1133).

${ }^{175}$ See n 171 (Russell noting this). Burridge himself was finally executed (aged 34) on 22 May 1722 for horse stealing. For his history, see GT Wilkinson, The Newgate Calendar - Pt 1 (Panther, 1962).

${ }^{176} R v$ Burridge (1735) $3 \mathrm{P}$ Wms 439 (24 ER 1133) at p 469, it was the opinion of the judges 'that the breaking of a prison wherein traitors are in durance, and causing them to escape, is treason, though the parties did not know that any traitors were there.' See also Limmerick's Case (1668) Kel (j) 77. For this latter case, see 84 ER 1087, at 1090.

${ }^{177}$ Hawkins, n 4, book 2, p 140 . See also n 171.

${ }^{178}$ Ibid. See also J Gabbett, A Treatise on Criminal Law (1843), vol 1, pp 884-6 (a useful summary). Also, pp 874-5 (re Bensted). See also R $v$ Fell (1698) 2 Salk 272 (91 ER 237). An indictment was brought against a jailer for negligently allowing a prisoner charged with treason to escape. Holt CJ 'It is not enough to say that he was charged, but he must also be said to be committed for high treason'. $R v$ Kendall and Row (1695) 1 Salk 346 (91 ER 304). A commitment for treason, in aid of prisoner committed for treason, must specify the treason for which committed. Holt CJ 'That Sir James Montgomery's treason ought to have been inserted into the warrant, with the allegation, that Sir James did the fact, because the defendants by breaking the prison, are guilty of the same specific treason and offence...' In neither of these cases did Holt CJ analyse the law in any detail and he seems keen to ensure that the defendants avoided a gruesome fate when not the principals. Sir James Montgomery (4th Baronet, d 1694) was involved in the Montgomery Plot, a scheme to restore James II (1685-8) to the throne.

${ }^{179}$ See n 89, p 406 'debruser le prison sciens [ie knowing] [les] prison[ers] ibidem fore pro proditione.' (italics supplied).

${ }^{180}$ Violating the wife of the sovereign etc, killing a judge of the king's bench (under the 1351 Act) and hindering the heir to the throne (under the 1702 Act) have never had a precedent. See: (a) High Treason: Killing the Sovereign or Her Judges (2009) 20 King's Law Journal 457-88; (b) High Treason: Violating the Sovereign's Wife (2009) Legal Studies, vol 29(2) 264-80; (c) Modernising English Criminal Law (2010) Coventry LJ, vol 15, no 2.

${ }^{181}$ Today, 'levying war' requires a civil war in which standards (vexillis) are raised against the sovereign and her army. This is somewhat unlikely. See generally, McBain, n 3, p 117. 
- Force. If a person escaped from prison without knocking down a roof tile, it was escape. If he knocked down a roof tile — even if unintentionally — it was a felony and he would hang for it; ${ }^{182}$

- Rescuers. If the prison was broken into by others and the prisoner escaped 'on the off chance', it was escape, not prison breach. But if he asked a friend to break in, who did, it was prison breach —and both would hang: ${ }^{183}$

- Fire. If a prisoner broke out of prison to save his life - because the prison was on fire-it was not escape or prison breach. If, after being free, he failed to return to prison, this would not then be escape or prison breach;

- Open Door. If a jailer held open a prison door for a fellow officer and a prisoner ran through it and escaped, it was escape. However, if a jailer failed to replace a rusty bolt and the prisoner pushed against it such that the door flew open and he escaped, it was prison breach and the prisoner would hang for it (because force was used);

- Treason. If a man escaping from prison helped a friend in his cell flee with him without being told what the latter was in prison for, it was likely a misdemeanour. But if the man told him, while in the prison, 'I'm here for HT' both would be hung, drawn and quartered. ${ }^{184}$ Yet, if the prisoner committed HT and broke prison alone, he would only be guilty of felony. ${ }^{185}$

All this was/is of little credit to the legal system.

\section{Courts, Constables, Prison Officers, Private Persons}

Much of the above analysis has considered the position, in particular, in respect of prisons. However, it also applies where a person seeks to escape etc., from the lawful custody of a constable, prison officer or private persons. Further, there still exists a distinct common crime relating to rescue from a court. I shall consider it first.

\section{(a) Rescue from a Court}

Coke (published in 1641) stated that:

If any man in Westminster hall, or in any other place, sitting the courts of chancery, the exchequer, the kings bench, the common bench, or before justices of assize, or justices of oier and terminer... shall draw a weapon upon any judge, or justice, though he strike not; this is a great misprision, for the which he shall lose his right hand, and forfeit his lands and goods, and his body to perpetual imprisonment: the reason hereof is, because it tendeth ad impedimentum legis terrae [to impede the law of the land]. So it is, if in Westminster hall or any other place, sitting the said courts there, or before justices of assise, or oier and terminer, and within the view of the same, a man doth strike a juror, or any other with weapon, hand, shoulder, elbow, or foot, he shall have the like punishment; but in that case, if he make an assault, and strike not, the offender shall not have the like punishment. ${ }^{186}$

Hawkins placed this crime, and others, under a general crime of 'contempt of the sovereign' which crime-a previous article asserts—-should be abolished. ${ }^{187}$

- The acts mentioned by Coke (drawing of a weapon) occurred, at times, in the case of persons being rescued from a court of law. Thus, in the case of O'Connor, tried for HT at Maidstone in 1798, there was a riot in open court as various people sought to rescue him; ${ }^{188}$

\footnotetext{
${ }^{182}$ Russell, $\mathrm{n}$ 4, vol 1, p 332 'the breaking need not be intentional.Thus where a prisoner made his escape from a house of correction, by tying two ladders together, and placing them against the wall of the yard, but in getting over threw down some bricks which were placed loose at the top (so as to give way upon being laid hold of) the judges were unanimously of opinion that this was a prison breach. $R v$ Haswell (1821) R \& R 458.' Russell also notes that 'The judge thought that if this had been an escape only, it would not have been felony.'

${ }^{183} \mathrm{Ibid}$, vol 1, p 332 'If the prison is broken by others without his procurement or consent, and he escapes through the breach so made, it seems that he cannot be indicted for the breaking out only for the escape.' Cf. If a person breaks into a prison and breaks the fetters of a woman committed for felony and tells her to go, but she does not, then no escape by her and, thus, no felony by him. $R v$ Osbern (1506), see SS, vol 116, Reports of Cases by John Caryll, p 535. See also J Baker, The Oxford History of the Laws of England, vol VI, 1483-1558 (Oxford UP, 2003), p 578.

${ }^{184}$ Exeter's Case, see 12. If he told him it was felony, both would be executed for felony. But what if he told him a false position (for example, that he was in for treason, but actually it was for a misdemeanour)?

${ }^{185}$ Hawkins, n 4, book 2, p 140.

${ }^{186}$ Coke, n 13, vol 3, p 140. Also, Blackstone, n 16, vol 4, p 125.

${ }^{187}$ See GS McBain, Abolishing some Obsolete Common Law Crimes (2009) 20 KLJ pp 98-102.

${ }^{188} \mathrm{He}$ had been found not guilty of HT but had not yet been released from the custody of the sheriff. The court was a special commission of oyer and terminer held in Maidstone, Kent.
} 
- The punishment for such an offence was forfeiture of land and goods, life imprisonment and amputation of the right hand for drawing a weapon (amputation, even if it could still be imposed in O'Connor's case was remitted by the sovereign). ${ }^{189}$

There is a further, but related, crime to this, where no weapon is drawn. Coke states:

If any do rescue a prisoner in or before any of the aforesaid courts committed by any of the aforesaid justices, it is a great misprision, for which he and the prisoner assenting to it, shall forfeit their lands and goods, and their bodies to perpetual imprisonment, but shall not lose the right hand, because no stroke or blow was given. ${ }^{190}$

This crime still exists and I am sure it will be re-assuring to a prisoner to know that, at least, his right hand will be safe. ${ }^{191}$ As to its modern formulation of this latter crime, Archbold (Blackstone's Criminal Procedure appears not to refer to it) states that it is a contempt of court (one in the face of the court):

To rescue or attempt by force to rescue a prisoner then being tried. ${ }^{192}$

Archbold cites the Earl of Thanet's Case (1799) without having regard to the fact that, in this case, the charges relating to contempt of the sovereign (that is, contempt in the face of the court) were withdrawn because of problems in respect of the punishment - especially amputation. Thus, the precise position today is left uncertain.

It is asserted this crime should now be the same as rescue from prison. And that both should become one of 'assisting' a person to escape. This would remove this antiquated common law crime, with all its complexities, and give it a modern formulation. The more serious crime of drawing a weapon upon any judge should also be abolished.

\section{(b) Constables, Prison Officers, Private Persons}

In respect of these, Archbold notes the following:

- Escape-Negligence of Officer. Where the escape is negligently permitted by an officer, the punishment is said to be a fine only. ${ }^{193}$ Archbold notes this appears to be erroneous and arise from a misconception of the nature of a fine in medieval times. ${ }^{194}$ One would agree. ${ }^{195}$ Further, this would seem to be inappropriate since the negligence of an officer is a greater dereliction than that of a private person and, thus, it should carry the same (or a greater) punishment - not a less. Archbold notes that it

\footnotetext{
${ }^{189}$ See $R$ v Earl of Thanet (1799) 27 ST 821 and Case Notes of Sir Soulden Lawrence 1787-1800, SS, vol 128, pp 205-7. Also, McBain, n 187, p 100, fn 74 and Hawkins, n 4, vol 1, ch 21 (of contempts against the king's courts), p 57. See also JH Baker, 'Le Brickbat Que Narrowly Mist' (1984) 100 LQR, p 544. In $R v$ Earl of Thanet, the Crown entered a nolle prosequi on such parts of the information as imposed a corporal penalty and in relation to forfeiture. Lord Thanet (Sackville Tufton, 9th Earl Thanet) was fined £1000, imprisoned in the Tower for a year and ordered to give security for his good behaviour. See also EH East, A Treatise of the Pleas of the Crown (London, A Strahan, 1803), pp 408-10.

${ }^{190}$ Coke, n 13, vol 3, p 140. He cites as authority for this YB 22 Edw 313 (actually YB 22 Edw 3 (1348) pl 26 fo 13 $3^{\text {a }}$, Seipp, n 68, no 1348.136, Common Pleas). In this case, one J made affray before (ie fought with, 'debat') Thorp J (Robert Thorp, assigned as a justice) who attached (arrested) him. A knight and a squire then fought with Thorp J by reason of which J escaped. A jury determing this, Shareshull JCP [JCP 1350-60] held that, because the knight and the squire had rescued J, the punishment was dis-inheritance and perpetual imprisonment (the knight to the Tower of London, the squire to Newgate prison). The hand of the squire who drew his sword to strike the justice was to be struck off. For J, for his fighting which resulted in the breach of his attachment, it was also dis-inheritance and perpetual imprisonment. See also Hawkins, n 4, book 1, ch 21, p 57 'Also he who rescues a prisoner from any one of the courts above-mentioned, without striking a blow, shall forfeit his goods and the profits of his lands, and suffer imprisonment during life, but not lose his hand, because he did not strike.' Blackstone, n 16, vol 4, p 125 (writing in 1769) 'A rescue also of a prisoner from many of the said courts, without striking a blow, is punished with perpetual imprisonment, and forfeiture of goods, and of the profits of lands during life: but looked upon as an offence of the same nature with the last; but only, as no blow is actually given, the amputation of the hand is excused.' See also Fox, n 128, p 236. See also cases in 1413, 1442, 1474 re rescue. Ibid, pp 238-40. See also BH Putnam, The Place in Legal History of Sir William Shareshull, Chief Justice of the King's Bench 1350-1361 (Cambridge UP, 1950), p 130.

${ }^{191} \mathrm{Cf}$. Baker, n 189, pp 546-7 'there is no very good reason for thinking that the amputation of a hand is not still a fixed penalty for commuting an act of violence in the presence of a judge sitting in a superior court.' Why the right hand? This would be the sword hand for right handed people. But what if the person was left-handed? The case of 1348 does not mention the court investigating this. See also Baker, p $545, \mathrm{n} 9$.

${ }_{192}$ Archbold, n 17, para 28-85.

${ }^{193}$ Ibid, para 28-174. It refers to Hawkins, n 4, book 2, c 19 (of escapes suffered by officers). Also, to Hale, n 4, vol 1, p 600 (touching negligent escapes) and to Russell, n 4,vol 1, p 327 (who simply refers to Hawkins). Cf SF Harris, Principles and Practice of the Criminal Law (17th ed, 1943), p 136 'A custodian, whether officer or private person, who negligently allows such a prisoner to escape, is guilty of a misdemeanor, punishable by fine and imprisonment.' Dalton, n 13 (written 1619), p 248 'Negligent escape, is when the party arrested or imprisoned, doth escape against the will of him that arrested or imprisoned him, and is not freshly pursued and taken againe before he hath lost the sight of him; the penalty thereof seeneth to be onely a fine at the discretion of the judges or justices: Yet see Stamf.35k [Staunford, $n$ 12] a difference of the fine, where the prisoner is attainted, where but indicted, and where onely taken upon suspicion.'

${ }^{194}$ It quotes Pollock \& Maitland, n 29, vol 2, p 517. Cf. The Boke for a Justyce of Peace (1534, Tho.Berthel), p 25 'if a felon escape out of the keeping of any goaler against his will, it is finable, the fine is a hundred shillings' (spelling modernised).

${ }^{195}$ See n 126.
} 
must be proved that the arrest and detention were lawful, that the defendant was a police constable and that he had the relevant person in custody under a lawful warrant. ${ }^{196}$ The fact of the escape must also be proved. It is not necessary to prove negligence on the part of the constable, since the law implies it. ${ }^{197}$ However, if the escape were not, in fact, negligent - if the escapee by force rescued ${ }^{198}$ himself - or was rescued by others - and the constable made fresh pursuit after him, but without effect, all this must be proved by the defence. Also, it is immaterial whether the relevant person was guilty of the offence for which he was arrested, provided the warrant justifies his detention; ${ }^{199}$

- Escape-Private Person. Where a private person negligently permits an escape, the punishment is fine and/or imprisonment. ${ }^{200}$ The offender must be restrained of his liberty for some criminal matter, otherwise the escape is not indictable at common law. Where the escape is due to the negligence of sheriffs or other officers, it may be dealt with under the Sheriffs Act 1887, s 29 or by attachment; ${ }^{201}$

- Escape-Voluntary-Officer. Archbold ${ }^{202}$ notes - as to evidence - that the conviction of the escapee must be proved. Also, that, on his conviction, the escapee was remanded or committed to the custody of the officer. It must also be proved the escapee was in the custody of the officer pursuant to his sentence. The fact of escape must also be proved. An escape is voluntary where the keeper gives the prisoner his liberty with the object of saving him from trial and punishment. ${ }^{203}$ Archbold asserts it seems ${ }_{204}$ unnecessary to prove the escape was voluntary; the law will presume this, until proved to the contrary.

- Escape-Voluntary-Private Person. The punishment is the same as for an officer. ${ }^{205}$

In relation to these matters today, one would question the following:

- Whether, today, an officer (whether a police constable or a prison officer) should be imprisoned and/or fined for a negligent escape. In the time of Hale, an escape was always presumed to be negligent in the officer. ${ }^{206}$ However, that cannot be so presumed today. Further, in times past, civil liability and employment law had not evolved to the extent they have done today. In modern times, a negligent officer should not face - it is asserted - a criminal charge. Rather, it should be an employment issue (gross misconduct meriting dismissal etc.) - especially where the escapee is in for a civil matter and not a crime. This should be even more so where a private person is negligent since, unlike past centuries, private persons are rarely called on to assist prisons officers and it is inappropriate to punish with

\footnotetext{
${ }^{196}$ Archbold, para 28-175 cites Hawkins, n 4, book 2, c 19, ss 1-4 (of escapes suffered by officers).

${ }^{197}$ Ibid. It refers to Hale, n 4, vol 1, p 600. Actually, it is p 601 'If a prisoner for felony break the gaol, this seems to be a negligent escape, because there wanted either that due strength in the gaol, that should have secured him, or that due vigilance in the gaoler or his officers to have prevented it, and therefore it is by law lawful for the gaoler to hamper them with irons to prevent their escape, and if this should not be construed a negligent escape, gaolers would be careless either to secure their prisoners, or to re-take them that escape, if he should in such a case be exempt from pecuniary punishment.'

${ }^{198}$ I think Archbold more properly intends to refer to prison breach.

${ }^{199}$ Archbold, n 17, para 28-175.

${ }^{200}$ Ibid. It refers to Hawkins, book 2, ch 19, s 6 (in fact, ch 20) 'In what manner a private person is punished for such an escape, I shall take it for granted that if it were voluntary, he is punishable in the same manner as an officer...and if it were negligent, he is punishable by fine and imprisonment, at the discretion of the court.' Hawkins refers to 19 Hen 7 c $10(1503$, rep) 'And if any person hereafter have any prisoner in his keeping, arrested for suspicion of felony, treason, or murder, and that person that is arrested, escape by negligent keeping, before that he be brought to the gaol, that person from whom he so escaped, shall forfeit for every person that doth escape, such fine as shall be set by the discretion of the justices that shall have authority to assess such fines, as the cause shall require, and the same forfeiture to go to them that be intituled to have such forfeitures at the time of making the said Act.' See also Russell, n 4, p 328.

${ }_{201}$ Archbold, n 17, para 28-174.

${ }^{202}$ Ibid, para 28-176. See also Dalton, n 13 (written 1619), p 248 'Voluntary escape, is where one doeth arrest, or hath imprisoned another for felony (or other offence) and after letteth him goe at liberty whither he will.' Cf. Boke, n 194, (in 1534) 'if any sheriff, gaoler, or any other person have let wilfully escape any felon, it is felony. And like wise if any bailiff, constable, or sheriff, or any other have taken any man for suspicion of felony and let him go, for he should have brought him to the next goal.' (spelling modernised).

${ }^{203}$ Hawkins, n 4, book 2, c 19, s 10 is cited. It states, in part 'where-ever an officer, who hath the custody of a prisoner, charged with and guilty of a capital offence doth knowingly give him his liberty with an intent to save him either from his trial or execution, he is guilty of a voluntary escape, and thereby involv'd in the guilt of the same crime of which the prisoner was guilty.' Also cited is Russell, $n$, vol 1, p 324 'According to the older authorities whenever an officer, having custody of a prisoner charged with, and guilty of, a capital offence knowingly gives him his liberty with an intent to save him, either from trial or execution, such officer is guilty of a voluntary escape and liable to the same punishment as the prisoner who he has allowed to escape.'

${ }^{204}$ Archbold, n 17, para 28-177. It refers to para 28-166. However, in neither case is authority cited and I do not believe it to be correct, since this presumption applies to negligent escape. This also is more reasonable - at least, in modern times (in the past, it would mean that a jailer was automatically presumed to have committed felony when a prisoner committed for felony escaped).

${ }^{205}$ Russell, n 4, p 328.

${ }^{206}$ See n 197.
} 
imprisonment or a fine. ${ }^{207}$ In conclusion, one would assert that negligence in an officer or a private person, should no longer be a crime;

- In modern times, should it be presumed that an escape was voluntary (see above)? Surely, the benefit of the doubt should be given to the constable/jailer? This also appears to conflict with the statement of Hale that negligence should be presumed; ${ }^{208}$

- As to a voluntary escape from a private person in the case of a criminal matter, one is dubious whether this should be a crime today. ${ }^{209}$ Rather, if it was egregious, it would seem better it be one of refusing to assist a constable who calls for assistance in dealing with a breach of the peace, this being a common law offence. ${ }^{210}$

In conclusion, one would assert that negligent escape should not be a crime. Nor voluntary escape from a private person. However, a voluntary escape permitted by an officer is as heinous as an escape, prison breach or rescue. Thus, it is asserted that the punishment should be the same.

\section{Modernising the Law}

In modern times, it is important the law be clear and intelligible — not least to prevent legal cases coming to court when they are not really necessary. As it is, the law on escape, prison beach and rescue is as clear as mud. This should not be so since the essential issue is not difficult: What should be the punishment for the escape of a person from lawful custody - or those assisting him? The reasons why the law became complex are not difficult to comprehend and have been adumbrated in this article. Today, it is asserted, the law can - and should — be greatly simplified. Thus:

- These offences should not be linked to the underlying crime (or asserted crime) for which a person is in prison or lawful custody_including in respect of any rescue or voluntary escape permitted by an officer; ${ }^{211}$

- A person who escapes (whether using force or not), a rescuer and an officer who deliberately lets a person go (i.e. a voluntary escape) should bear the same punishment since they are equally culpable. So too, a person harbouring an escapee;

- The imposition of fines in this area should be abolished. ${ }^{212} \mathrm{So}$, too any additional punishment in the case of treason, although it is asserted this no longer exists (see 12);

- The words 'prison breach' are a mis-nomer since it can occur in the case of a forcible escape other than from a prison. This offence and the other common law offences of escape and rescue should be abolished. Instead, there should be statutory crimes of 'escape' and 'assisting a person to escape.'

Thus, the key to the modern crimes should be a simple distinction between: (a) a 'designated place'; and (b) a 'designated person'.

- The former should include not only prisons but also equivalent reformatories, such as young offenders' institutions. Also, a court, since to escape from a court (or to be rescued from the same) is as much a serious affront to (and an attempt to undermine) justice as is the same in the case of a prison;

- The latter should include when a person is in the lawful custody of a constable, prison officer or private person.

Thus, in conclusion, there should be two principal crimes: to escape and assisting escape.

- $\quad$ Escape. It should be a crime to escape from:

$$
\text { ○ a designated place; }{ }^{213} \text { or }
$$

\footnotetext{
${ }^{207}$ See Hale, vol 1, p 601 where he accepts that the private person must have a lesser degree of responsibility. 'if a private person arrest a felon, and he escape by force from him without any default in him, tho the township shall be amerced, as shall be said, yet it seems it excuseth the party, for he being a private person cannot raise power to take or detain a felon.'

${ }^{208}$ See n 197.

${ }^{209}$ In past times, it was draconian. Hale, n 4, vol 1, p 595 held that a private person who arrested a felon and then let him escape committed felony (reason enough for private persons to avoid getting involved!). However, if the felon escaped without the fault of the private person, it excused the latter (Ibid, p 601 and n 207). This position concerning a private person has changed dramatically since the time of Hale. Hue and cry and a non-professional police force have long gone. Also, the police, today, generally dissuade private persons from becoming involved. Finally, as to the involvement of private persons in prisons, this is no longer apposite.

${ }^{210}$ See Brown (1841) Car \& M 314 and Waugh (1976), The Times (1 October 1976).

${ }^{211}$ In this, the decision in $R v$ Frascati (2006), see $\mathrm{n} 129$, is not only important but correct (and should also apply in the case of treason).

${ }^{212}$ Not only are modern day fines wholly different from medieval amercements and fines but fines, presently, are being applied inconsistently in this area. .
} 
$\circ$ the lawful custody of a designated person. ${ }^{214}$

This should apply regardless of whether force is used or not; since this should go to the sentence, not to the crime. ${ }^{215} \mathrm{~A}$ 'designated person' should apply to a private person only in respect of a criminal matter. The crime of conspiring to escape from lawful custody also exists and it is asserted that conspiracy should apply to both the above crimes; ${ }^{216}$

- $\quad$ Assisting Escape. It should be a crime to assist a person to escape, or attempt to escape, from:

○ a designated place; ${ }^{217}$

○ the lawful custody of a designated person.

This should apply regardless of whether force is used or not. At present, it is not clear whether it is a crime to do this in respect of a designated person. The result is that the law of conspiracy is used, when it would seem better to make this a substantive offence. ${ }^{218}$ At present, it is a distinct crime (Prison Act 1952, s 39, see 9(ii)) to 'facilitate' the escape of a prisoner, by intentionally: (i) bringing, throwing or otherwise conveying any thing into a prison; (ii) causing another person to bring, throw or otherwise convey any thing into a prison, or (iii) giving any thing to a prisoner or leaving any thing in any place (whether inside or outside a prison). ${ }^{219}$ There is no need for this. This should now merge with the concept of 'assisting escape' and apply not just to a prison but to a 'designated place'. Thus, 'assisting' should include intentionally doing (i)-(iii);

- Harbouring an Escapee. Presently, it is a crime to knowingly harbour a person who: (a) has escaped from a prison; or (b) who, having been sentenced in any part of the UK (or in any of the Channel Islands or the Isle of Man) to imprisonment or detention, is otherwise unlawfully at large. It is also a crime to give such a person any assistance with intent to prevent, hinder or interfere with his being taken into custody. See Criminal Justice Act 1961, s 22 (see 9(ii)). There is no need for this. This should also be merged into the concept of 'assisting escape' andit should apply to any 'designated place'.

Besides the above crimes of escape and assisting escape, there should be a further crime.viz

- Failure to Return after Temporary Release. It should be a crime to fail to return to prison after temporary release. This will replicate the Prisoners (Return to Custody) Act 1995 (see 9(ii)). However, this should not apply only to prison but also to any reformatory.

As to the sentence, there should be imprisonment, but no fine. At present, the position in respect of the above crimes is inconsistent and confused. As to the maximum period of imprisonment, one would suggest that:

- For the current offences of escape (with, or without, force), ${ }^{220}$ assisting escape, ${ }^{221}$ rescue, ${ }^{222}$ voluntarily permitting an escape, ${ }^{223}$ facilitating an escape ${ }^{224}$ and harbouring an escapee ${ }^{225}$ - in the case of a designated place - the maximum sentence for the new crime of escape or assisting escape should be the

\footnotetext{
${ }^{213}$ This will combine escape (without force) and prison breach (with force). 'Designated place' should cover a prison, a police station, a place under the Mental Health Act (see 9(c)), a young offenders institution, a court (when there in respect of a criminal matter and whether or not in the actual custody of a constable, prison officer or member of court staff) etc. However, the punishment under the Mental Health Act should be less, see text. Consideration should also be given to making a 'prison van' a designated place. This would then effectively cover the whole cycle of police station, court, prison - including transit. In all these cases, the crime and the level of punishment should really be the same.

214 'Lawful' or 'legal' custody? The former seems a better word since, where a person is taken into custody but it is not lawful, no crime is committed. For a prison officer, see Prison Act 1952, s 8. See also Armed Forces Act 2006, s 29 (offence in relation to service custody).

${ }^{215}$ This is what effectively happens at present, see Archbold, n 17, para 28-181. See also Blackstone CP, n 19, B14.70.

${ }^{216}$ In a recent case, a drugs dealer (John Anslow), serving a 22 year sentence, was sentenced to 7 years for conspiring to escape from lawful custody (on his way to court, he was freed from a prison van by masked gunmen). A prison officer was also sacked after an internal investigation. See BCC News, 5 April 2014. For conspiracy generally see Archbold, n 17, ch 33.

${ }^{217}$ This will cover rescue as well as a prison officer (or police constable) permitting voluntary escape. It merges these common law crimes with the Prison Act 1952, s 39 (see 9(ii)).

${ }^{218}$ For example, see $\mathrm{n} 216$. Here, his accomplices, in reality, 'assisted' Anslow to escape from the prison van.

${ }^{219}$ It says a 'felony'. See also Russell, n 4, vol 1, p 337, $R$ v Payne (1866) LR 1 CCR 27 and Archbold, n 17, para 28-168. A person is guilty of assisting a prisoner to escape from prison even if the escape occurred while the prisoner was doing work outside the prison. $R v A b b o t t$ [1956] Crim LR 337.

${ }^{220}$ For escape and prison breach the punishment is the same, fine and/or imprisonment. Archbold, n 17, paras $28-172 \& 183$.

${ }^{221}$ See Prison Act 1952, s 39 (liable on indictment to a maximum sentence of imprisonment of 10 years).

${ }^{222}$ The sentence is the same as escape and prison breach, see n 218 and Archbold, n 17, para 186.

223 The sentence is the same as for rescue, see $n 220$.

${ }^{224}$ The sentence is the same as for assisting an escape, see n 219. See also Bowman (1997) 1 Cr App R (S) 282 (7 years for conspiracy to assist a prisoner to escape from jail by smuggling a pistol into the jail).

${ }^{225}$ Criminal Justice Act 1961, s 22 (on indictment, a maximum sentence of 10 years or a fine or both). See also Archbold Procedure, para 20140 .
} 
same. Perhaps, 10 years would be appropriate — save in cases under the Mental Health Act. ${ }^{226}$ When the same is escape or assisting escape in the case of a designated person, perhaps, 5 years would be appropriate, in order to deter;

- Failure to return after temporary release. It is asserted this should bear the current punishment (6 months) without the element of a fine. ${ }^{227}$

Finally, as to:

- An officer who negligently permits an escape - this should be a matter of employment law (dismissal, demotion etc.) rather than of criminal law; ${ }^{228}$

- A private person who negligently permits an escape - this should not be a crime (whether fine or imprisonment). Nor if the same permits a voluntary escape. ${ }^{229}$

If there above modernisation of the law were undertaken, it would make the law more intelligible (and rational). It would also save the public purse through less court cases and wasted legal time.

\section{$\underline{\text { Appendix A }}$}

1. Escape $^{230}$

(a) It is a crime ('escape') for a person to intentionally escape from: (i) lawful custody in a designated place; or (ii) the lawful custody of a designated person.

(b) Escape is committed whether or not force is used.

(c) For escape to be committed, the person must know he is in custody or be reckless whether he is or not;

(d) The punishment for escape is imprisonment not exceeding 10 years.

'Designated place' means any: (i) prison; (ii) young offender's institution; (ii) remand centre; (iv) criminal court;

'Designated person' means any: (i) police officer; (ii) prison officer or other officer of a designated place; (iii) private person in respect of a criminal matter.

'Custody' includes where a person is in custody when:

(i) under arrest;

(ii) held in a police station;

(iii) awaiting trial;

(iv) awaiting sentence;

(v) serving a sentence;

(vi) in transit to, or from, a designated place (including a prison van);

(vii) attending a criminal court for trial or sentence;

(viii) confined in any designated place;

(ix) under the control of the governor of a designated place;

(x) under the control of a prison officer or other officer of a designated place (and whether inside, or outside, a designated place for the purpose of work or for any other reason);

(xi) while being taken, or kept, in custody in any place to which he is required, or authorized, under any criminal legislation.

\footnotetext{
${ }^{226}$ See Mental Health Act 1983, s 128 (summarily, imprisonment not exceeding 6 months or a fine not exceeding the statutory maximum, or to both. On indictment, to imprisonment not exceeding 2 years or a fine of any amount, or both).

${ }^{227}$ See Blackstone CP, n 19, B14.72. At present, the and/or fine shall not exceed level 5.

${ }^{228}$ See $\mathrm{n} 216$.

${ }^{229}$ The crime, instead, would be (where applicable) the common law crime of refusing to assist a police constable.

${ }^{230}$ This covers escape and prison breach at common law.
} 


\section{2. $\quad$ Assisting Escape ${ }^{231}$}

(a) It is a crime ('assisting escape') for a person to intentionally assist a person to escape, or attempt to escape, pursuant to section 1 .

(b) Assisting escape is committed whether or not force is used.

(c) The punishment for assisting escape is imprisonment not exceeding 10 years.

'Assisting escape' includes the following:

(i) if a person, intending to facilitate an escape, (a) brings or throws or otherwise conveys any thing into a designated place; (b) causes another person to bring, throw or otherwise convey any thing into a designated place; or (c) gives any thing to a person detained in a designated place; or (d) leaves any thing in any place (whether inside or outside a designated place);

(ii) if a person knowingly harbours a person who: (a) has escaped from a designated place; or (b) having been sentenced in any part of the UK (or in any of the Channel Islands or the Isle of Man) to imprisonment or detention, is otherwise unlawfully at large; (c) assists a person referred to in (a) or (b), intending to prevent, hinder or interfere with his being taken into lawful custody.

\section{Assist Absence from Hospital Etc.}

(a) It is a crime to induce, or intentionally ${ }^{232}$ assist, a person who is: (a) liable to be detained in hospital; or (b) subject to guardianship under the Mental Health Act 1983; or (c) a community patient; to absent himself.

(b) It is a crime to induce, or intentionally assist, a person in lawful custody under the Mental Health Act 1983 to escape, or to harbour or assist a person unlawfully at large, to remain at large.

(c) The punishment for the crime in (a) or (b) is imprisonment not exceeding 2 years.

\section{Failure to Return after Temporary Release}

(a) It is a crime ('failure to return after temporary release') if a person temporarily released in pursuance of rules made under s 47(5) of the Prison Act 1952: (i) without reasonable excuse, remains unlawfully at large at any time after becoming so at large by virtue of the expiry of the period for which he was temporarily released; or (ii) knowing (or believing) an order recalling him to have been made and while unlawfully at large by virtue of such an order, fails, without reasonable excuse, to take all necessary steps to comply as soon as reasonably practicable with that order.

(2) The punishment for failure to return after temporary release is imprisonment not exceeding 6 months.

\section{Copyrights}

Copyright for this article is retained by the author(s), with first publication rights granted to the journal.

This is an open-access article distributed under the terms and conditions of the Creative Commons Attribution license (http://creativecommons.org/licenses/by/3.0/).

\footnotetext{
${ }^{231}$ This covers rescue at common law or a constable, prison officer or private person permitting voluntary escape.

${ }^{232}$ The former word was 'knowingly'. However, 'intentionally' would seem better.
} 